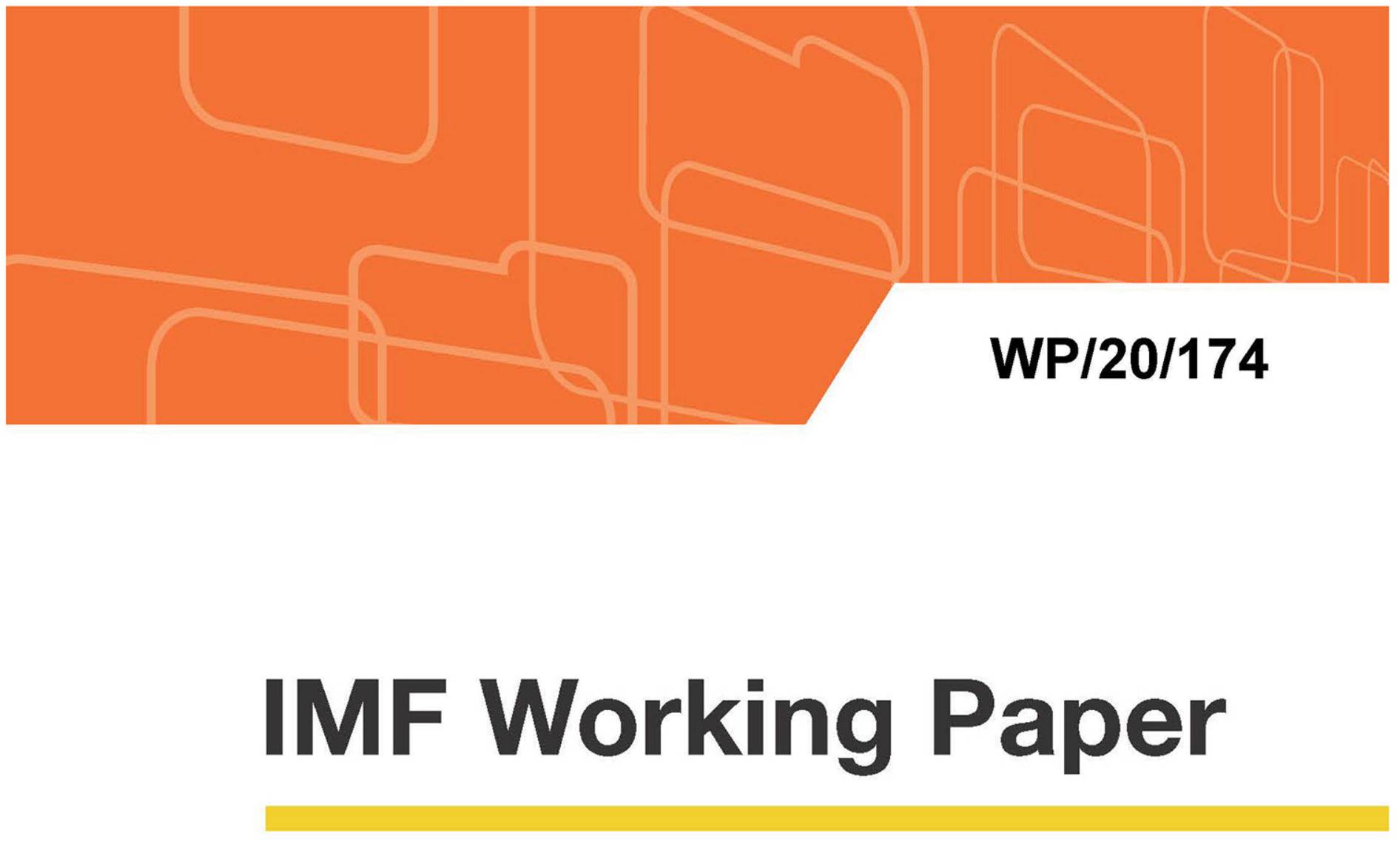

\title{
Non-Primary Home Buyers, Shadow Banking, and the US Housing Market
}

by Adrian Alter and Zaki Dernaoui

IMF Working Papers describe research in progress by the author(s) and are published to elicit comments and to encourage debate. The views expressed in IMF Working Papers are those of the author(s) and do not necessarily represent the views of the IMF, its Executive Board, or IMF management. 


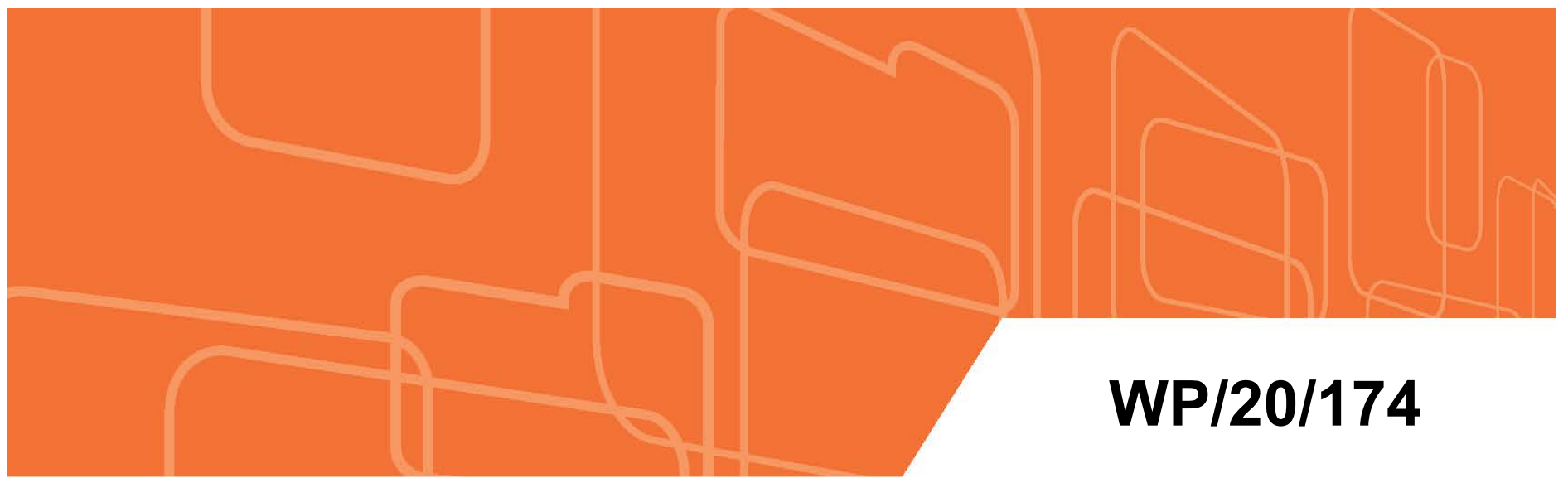

IMF Working Paper

\section{Non-Primary Home Buyers, Shadow Banking, and the US Housing Market}

by Adrian Alter and Zaki Dernaoui

IMF Working Papers describe research in progress by the author(s) and are published to elicit comments and to encourage debate. The views expressed in IMF Working Papers are those of the author(s) and do not necessarily represent the views of the IMF, its Executive Board, or IMF management.

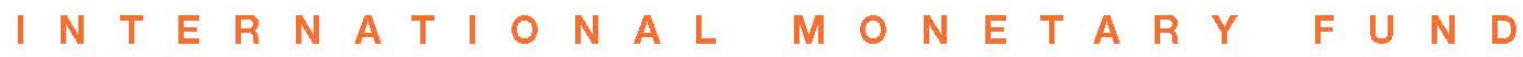




\title{
IMF Working Paper
}

Monetary and Capital Markets Department

\section{Non-Primary Home Buyers, Shadow Banking, and the US Housing Market ${ }^{1}$}

Prepared by Adrian Alter and Zaki Dernaoui

Authorized for distribution by Prasad Ananthakrishnan

August 2020

\begin{abstract}
IMF Working Papers describe research in progress by the author(s) and are published to elicit comments and to encourage debate. The views expressed in IMF Working Papers are those of the author(s) and do not necessarily represent the views of the IMF, its Executive Board, or IMF management.
\end{abstract}

\begin{abstract}
This paper studies the US housing market using a proprietary and comprehensive dataset covering nearly 90 million residential transactions over 1998-2018. First, we document the evolution of different types of investment purchases such as those conducted by short-term buyers, out-of-state buyers, and corporate cash investors. Second, we quantify the contributions of non-primary home buyers to the housing cycle. Our findings suggest that the share of shortterm investors grew substantially in the run-up to the global financial crisis (GFC), which amplified the boom-bust cycle, while out-of-state buyers propped up prices in some areas during the recession. An instrumental variable approach is employed to establish a causal relationship between housing investors and prices. Finally, we show that the recent rise of shadow bank lending in the residential market is associated with riskier mortgages, and explore its implications for non-primary home buyers and its effects on house prices and rents.
\end{abstract}

\section{JEL Classification Numbers: D14; G12; G23; R31}

Keywords: house prices, non-traditional investors, shadow banking

Authors' email addresses: aalter@imf.org, zaki@mit.edu

\footnotetext{
${ }^{1}$ Zaki Dernaoui interned in the IMF's Monetary and Capital Markets Department (MCM) during summer 2019. We are grateful to Prasad Ananthakrishnan, Daniel Andrei, Nina Biljanovska, Neesha Harnam, Deniz Igan, Junghwan Mok, James Morsink, Machiko Narita, Christopher Palmer, Marco Pani, David Thesmar, Radu Tunaru, and Emil Verner, as well as participants in the IMF seminar and MIT Brown Bag Lunch for insightful comments and suggestions. We are highly indebted to Cristian Badarinza, from NUS, for detailed comments and suggestions. We thank Elizabeth Mahoney for excellent research assistance and Katya Botsu for editorial assistance. The views expressed in this paper are those of the authors and do not necessarily represent the views of the IMF, its Executive Board, or IMF management. Data were provided by Zillow through the Zillow Transaction and Assessment Dataset (ZTRAX). More information on accessing the data can be found at http://www.zillow.com/ztrax. The results and opinions are those of the authors and do not reflect the position of Zillow Group, Inc.
} 
Table of Contents

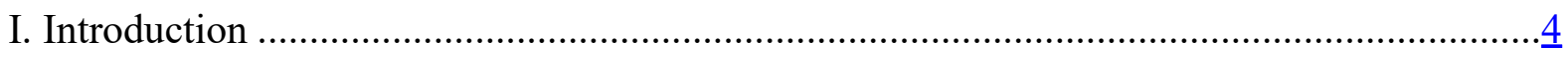

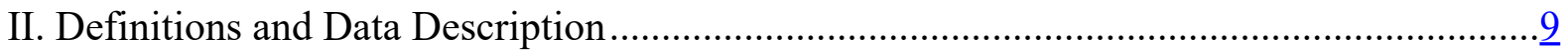

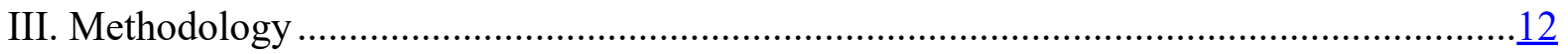

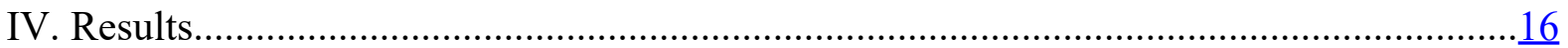

A. House Prices and Non-Primary Home Buyers .....................................................................

B. The Role of Non-Bank Lending ......................................................................................

C. Zooming in: Non-Bank Lending and Riskier Mortgages .........................................................

D. Instrumental Variable Analysis ....................................................................................... 18

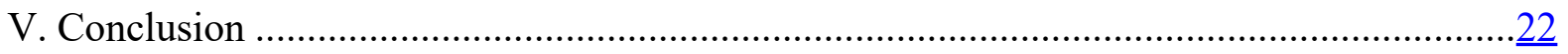

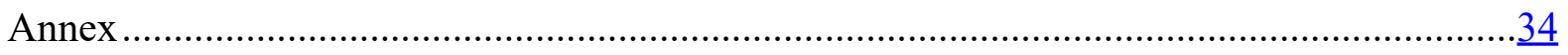

Figures

1. Non-Primary Home Buyers and Transaction Volume ........................................................

2. Foreclosure Sales and First-Look Properties ……….................................................

3. First Look Program and Non-Primary Home Demand .....................................................

Tables

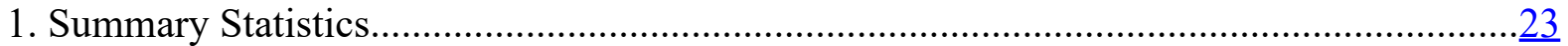

2. A. House Prices and Non-Primary Home Buyers...........................................................

2. B. Housing Rent and Non-Primary Home Buyers............................................................

3. Non-Bank Lending, Non-Primary Home Buyers, and House Prices......................................26

4. Non-Bank Lending, Riskier Mortgages, and House Prices ………………………...........27

5. Non-Bank Lending and Riskier Mortgages ...................................................................

6. First Look Program and Non-Primary Home Demand ...................................................29

7. House Prices and Non-Primary Home Demand - IV 2SLS Estimations ...............................

8. Rental Index and Non-Primary Home Demand - IV 2SLS Estimations................................ 


\section{INTRODUCTION}

Non-bank financial intermediation has become increasingly prominent in residential mortgage lending over the past decade, after plummeting during the Global Financial Crisis (GFC). Prior to the GFC, mortgage loans intermediated by shadow banks represented more than 60 percent of total residential lending, reflecting the prominence of the "originate-and-distribute" model. Regulatory changes in the banking industry and the use of new technologies to screen borrowers have significantly contributed to the rebound of shadow banking activity (Buchak and others 2018; Fuster and others 2019)2.

In contrast to the subprime lending hypothesis, recent studies have provided new evidence that the presence of middle-class borrowers, out-of-town buyers, and institutional investors in the residential real estate market during 2000-06 contributed substantially to the US housing boom (Albanesi and others 2017; Chinco and Mayer 2016; Adelino and others 2016; Favilukis and Van Nieuweburgh 2017; Mills and others 2019). Moreover, in the aftermath of the great housing bust, real estate investors such as cash-rich corporates and wealthy individuals with multiple properties filled the demand vacuum and stabilized the housing market. Ten years after the GFC, the housing market in the US has recovered, with prices exceeding the peak of the previous boom. At the same time, private label securitization and mortgage credit originated by shadow banks have rebounded.

This paper investigates the interplay between non-traditional housing investments, credit supply expansion outside the banking sector, and the residential real estate market in the US, and also attempts to fill the gap in understanding the effects on house price cycles. Speculation is a critical channel through which credit supply expansion can amplify the housing cycle. One of the main novelties in this paper is the sheer range of housing transactions analyzed, including mortgage purchases and house sales paid fully in cash. In addition, our data allow us to distinguish between various types of buyers, including individual and corporate investors, and, on the credit supply side, identify whether the mortgage was originated by a bank or a nonbank lender. These transaction-level features allow us to unveil new evidence on the role of non-traditional investors in the residential market.

Conceptually, different types of real estate investors may exert varying contributions to the house price cycle, due to heterogeneous preferences and expectations (DeFusco and others, 2017; Armona and others, 2019). Most of the recent literature has focused on mortgage data, ignoring cash transactions. A key reason for this focus is the lack of comprehensive transaction data. However, the inclusion of all transactions allows for a more comprehensive analysis, given that cash purchases constitute roughly 30 percent of total residential volume. The empirical strategy used in this paper relies on proprietary data from Zillow Transaction and Assessment (ZTRAX), a transaction-level database collected from individual deed records that include all types of sale transactions in the United States, both financed by mortgages and in cash, over the 1996-2018 period.

\footnotetext{
2 "Non-bank financial intermediation" and "shadow banking" are used interchangeably throughout this paper. We define as "shadow banks" those financial intermediaries other than banks and credit unions.
} 
Figure 1 depicts different shares of non-primary home buyers such as cash purchases made by corporations, properties that are resold within a 12-month period, out-of-state investors, and second-home purchases. Collectively, the share of non-traditional buyers started to pick up significantly during the period prior to the GFC. This aggregated share reaches its peak in mid2011, when total transaction volume and residential real estate prices bottomed out. Both corporate cash transactions and within-year resale activity dramatically increased when prices tanked in 2008-09, more than tripling the pre-crisis levels. Overall, more than 30 percent of residential home sales were transacted by non-primary home buyers during the 2008-12 period. Their total share consistently declined over the next years, reaching about 15 percent of total transaction volume at the end of 2018.

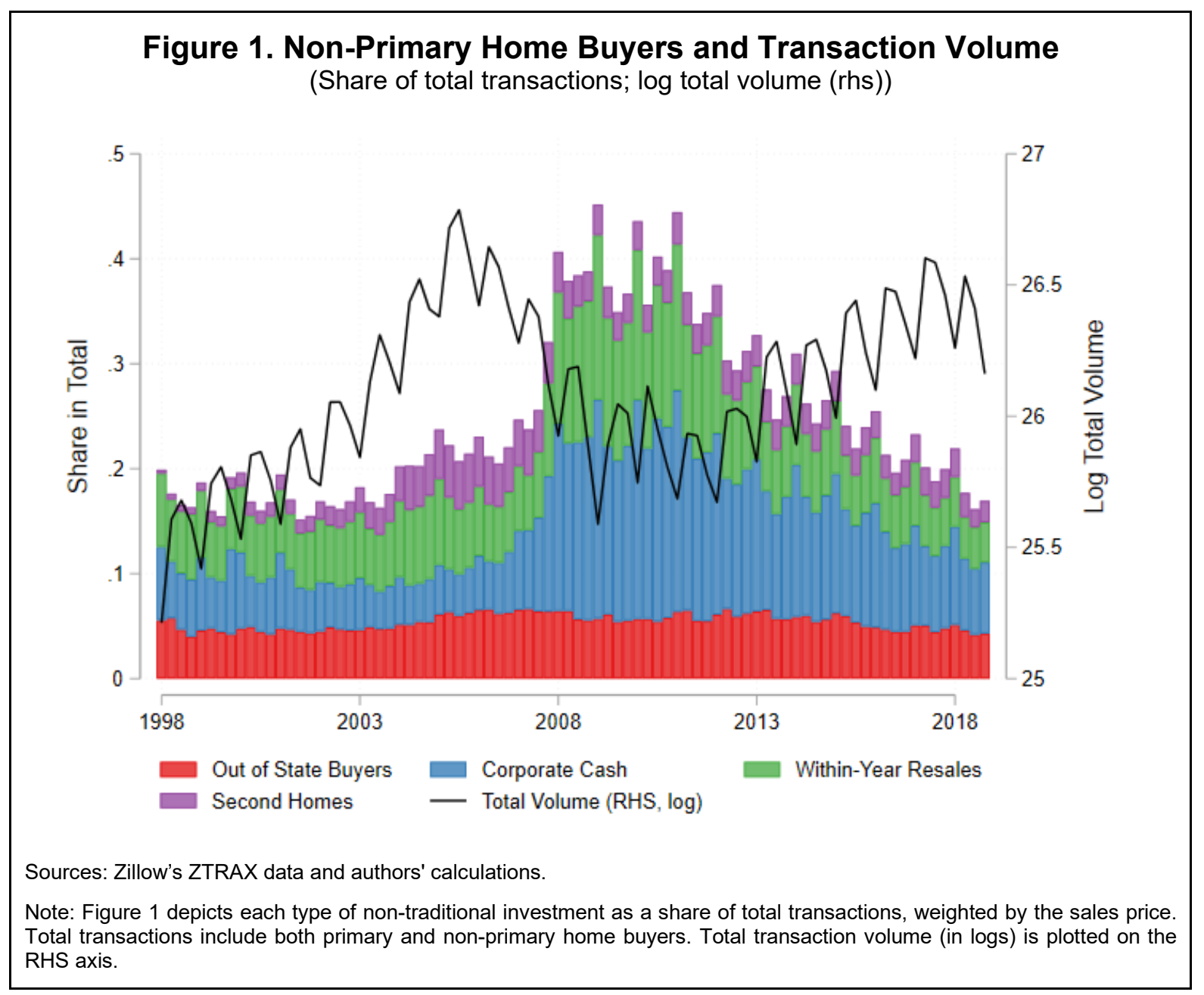

The main questions presented in this paper are as follows: (1) How are different non-primary home buyers affecting house price cycles? (2) Has the increasing share of non-bank lending affected the housing market? (3) Which investors are more relevant during boom-bust periods? and (4) What is the link between credit supply by shadow banks and non-traditional buyers over the cycle?

Looking through different lenses, our findings point to several novel and interesting features of the US residential housing market. The contributions of this paper are threefold. 
First, we document the evolution of non-traditional buyers and capital invested in the US residential housing market. For example, the share of corporate cash transactions increased substantially in the aftermath of the GFC and peaked in 2011, when the US housing market started to recover. When the housing market collapsed in 2008-09, market timing activity, identified by transactions where the buyer resells the property within a short period of time, surged, helping to improve market liquidity. Subsequently, we assess the relationship of nontraditional buyers to house price cycles and rents. We find compelling evidence that secondhome buyers and short-term investors are amplifying prices throughout the housing cycle. In contrast, an increase in the share of out-of-state buyers props up house prices, especially during the bust when liquidity dries up. At the same time, non-primary home buyers are consistently found to have negatively affected rent growth, with the largest effects observed for short-term and second-home investors, and to a lesser extent, for out-of-state buyers.

Second, we explore the link between credit supply, non-traditional buyers, and house prices by teasing out the heterogeneity across zip codes. As previously noted, speculation is a critical channel through which an excessive increase in credit supply could amplify the housing cycle. We find firm evidence in our data confirming this channel. The housing cycle and household indebtedness have historically moved in tandem; this co-movement has been strengthened by the rapid growth of securitization and shadow banking activity in the early 2000s (see, for example, Mian and Sufi 2018a; Keys and others 2010; Demyanyk and Van Hemert 2011; Justiniano and others 2019; Nathanson and Zwick 2018) ${ }^{3}$. Relying on credit supply information, we find that areas with a higher penetration of shadow banking mortgage activity are disproportionately affected by non-traditional buyers, particularly second-home buyers and short-term investors. In addition, our findings suggest that a higher share of loans originated by non-bank financial intermediaries is typically associated with a short-term amplification of the housing cycle.

Third, we exploit a quasi-experimental setting to assess the role of second-home buyers on price dynamics. Relying on an instrumental variable analysis, we identify causal effects of non-primary home demand on the housing market, in particular on prices. Starting in 2009-10, government sponsored enterprises (GSEs) implemented the First Look program to encourage home ownership by allowing households' owner-occupiers to purchase foreclosed properties owned by GSEs, during a window of up to 20 days, before other investors could make a bid on the property ${ }^{4}$. Similar to Lambie-Hanson and others (2019), we exploit the geographical variation in share of foreclosure sales owned by the GSEs as an instrument to quantify the effect of investors in the housing market. We find that second-home investment demand had an economically and statistically significant impact on house prices. We also investigate the relationship between non-primary home investment demand and rent prices. We show that the

\footnotetext{
${ }^{3}$ Developing a theoretical model, Greenwald and Guren (2019) find that changes in credit conditions can explain 28 to 47 percent of the rise in price-rent ratios over the boom. In addition, they show that credit-insensitive agents such as landlords and unconstrained savers absorb credit-driven demand, which depends on the degree of segmentation in housing markets. Relatedly, cities that were more exposed to mortgage credit supply shocks experienced a larger increase in household investment activity during the housing boom (Mian and Sufi 2018b).

${ }^{4}$ This program was implemented in all zip codes where Fannie Mae and Freddie Mac owned mortgages.
} 
rise in investment purchases helped decelerate the increase in rental prices, indicating that a supply channel of rental properties may be at play.

Quantifying the consequences of speculation in the housing market is a long-standing question in the economic literature. Researchers are facing two major challenges when tackling this question: (1) obtaining comprehensive and detailed data, including purchases made with or without a mortgage; and (2) the endogeneity issue permeating the analysis of the impact of non-primary home buyers on house prices. For example, the opening of a new Amazon office in a given area can boost local economic activity, drive up the local demand for office space and housing, and attract additional investment capital, including in real estate and for services such as restaurants and childcare. This paper uses transaction-level deed records to show how non-traditional buyers affect the boom-bust housing cycle. Moreover, we link the likelihood for non-traditional investments to shadow banking activity. Crucially, we use a novel identification strategy to address the issue of reverse causality and endogeneity by examining the First Look program. A key advantage of our instrumental variable approach is that it relies on zip code-level variation, allowing us to establish a causal link between investors and house prices.

Our study is related to the existing literature highlighting the role of investors in explaining the housing boom-bust cycles over the past three decades, including the GFC. Relying on a theoretical model, Burnside and others (2016) show that substantial differences in expectations about long-term fundamentals typically lead to boom-bust episodes in housing markets. On the empirical side, Bhutta (2015) and Albanesi and others (2017) focus on real estate investors, showing that areas with larger boom-bust cycles were associated with a larger increase in investor share and speculative behavior, while short-term investors amplified volume and price movements. ${ }^{5}$ Using transaction level data from deed records in 21 cities over 2001-07, Chinco and Mayer (2015) find that out-of-town second-home buyers tend to buy at the peak of the house price cycle and realize lower capital gains relative to local investors ${ }^{6}$. Interestingly, Adelino and others (2016) argue that middle-income households borrowed extensively prior to the GFC for investment purposes, fueling the housing bubble. Similarly, Lambie-Hanson and others (2019) document the rising trend in institutional investors as both buyers and sellers in the US residential market in the aftermath of the GFC. Using transaction-level data, they find that institutional investors facilitated the recovery of the local housing markets, but at the expense of lower homeownership rates. Finally, Gao and others (2020) study the role of speculation in residential housing markets using mortgage data and an instrument exploiting across-state variations in the capital gains tax rates. They argue that speculation, as defined by

\footnotetext{
${ }^{5}$ Relatedly, Foucault and others (2011) show that speculative activity by retail investors increases volatility in the stock market.

${ }^{6}$ Similarly, international capital flows channeled by foreign housing investors have led to significant increases in house prices for globally interactive cities such as London, New York, and Vancouver (Badarinza and Ramadorai 2017), with housing price cycles becoming increasingly synchronized (Alter and others 2018). This development has been typically attributed to the demand for safe assets, low interest rate environment, and a financialization of housing assets. Similarly, recent studies (Ari and others 2020; Alter and Mahoney 2020) find that foreign purchases of real estate increase local house prices in the US, potentially increasing future downside risks to prices. Intuitively, cities in which house prices are more sensitive to foreign capital flows have previously experienced higher levels of immigration.
} 
second home buyers, amplified the boom-bust cycle in the US residential markets. Our work expands on those results by using a more comprehensive and granular dataset on transactions, including those made in cash, and with a broader geographical coverage. This approach allows for a more precise quantification of non-primary home investment demand. We also expand on the existing literature by using an instrumental variable with finer variations across zip codes and quarters.

Naturally, with more than 60 percent of transactions being financed by loans, credit supply and credit shocks play a key role in housing market dynamics. Several related aspects of this situation are highly relevant. First, housing investment is highly leveraged, creating risks for both homeowners and their lenders. Second, shadow banking activity is now quite robust, as it rebounded in the aftermath of the GFC, partially driven by tighter regulation for the banking sector and the emergence of new technologies (Buchak and others 2018; Fuster and others 2019). At the same time, non-bank financial intermediation has been typically associated with lower lending standards such as high loan-to-value ratios (LTVs) or poor FICO scores. Areas with high shares of subprime borrowers witnessed larger relative growth in mortgage originations for house purchases and house prices from 2002 to 2005 (Mian and Sufi 2009).

The rest of the paper is structured as follows: Section II presents the main characteristics of our comprehensive data and introduces various definitions, including the types of non-primary home investment and credit supply features used in this paper. Section III outlines the two empirical approaches employed in our analysis to gauge the role of non-primary home buyers and shadow bank lending on house price cycles and rents. Section IV quantifies the effects of non-primary home investments on house price cycles, including the use of an instrumental variable approach that allows for more causal interpretations. Section V presents conclusions. 


\section{DEFINITIONS AND DATA DESCRIPTION}

In this paper, we consider four groups of non-traditional home buyers. Subsequently, we aggregate their individual shares in total sales, weighted by the sale amount, for each zip code and quarter. Initially, we define the overall number of sales, followed by various types of nontraditional investors, non-bank lending, and other definitions.

Definition 1 (total house sales). Define $N_{i, q}$ as the quarterly number of residential real estate units sold in zip code $i$. The total number of sale transactions refers to both paid in cash and loan-financed residential units, with $N_{i, q}=C_{i, q}+L_{i, q}$.

\section{Non-Primary Home Investment Demand}

Definition 2 (second-home buyers). Define $S H_{i, q}$ the quarterly number of transactions involving second-home properties that are non-owner occupied in zip code $i$. The share of second-house properties in total transactions is defined as $\frac{S H I_{i, q}}{N_{i, q}}$, weighted by the sale price.

Definition 3 (short-term buyers). The definition of short-term buyers (or market timers) is based on sale transactions where the same property is bought and sold within a 12-month window. Using the parcel number, which uniquely identifies each property, we can identify transactions where an investor buys and resells the same property in a short period of time. Let $S T_{i, q}$ be the quarterly number of transactions involving short-term investors in zip code $i$, then the fraction of short-term investors is $\frac{S T I_{i, q}}{N_{i, q}}$, weighted by the sale price.

Definition 4 (corporate cash buyers). Corporate cash buyers refer to transactions involving a non-individual buyer (for example, LLC), where no mortgage loan is associated with the purchase. The share of corporate cash buyers is defined as $\frac{L L C_{i, q}}{N_{i, q}}$, weighted by the sale price.

Definition 5 (out-of-state buyers). Out-of-state buyers are identified by comparing the property address with the buyer's tax address. Following Chinco and Mayer (2016), we rely on the deed information to extract the state in which the buyer resides and the state of the property. The fraction of out-of-state buyers is defined as $\frac{O S B_{i, q}}{N_{i, q}}$, weighted by the sale price.

\section{Other Definitions}

Definition 6 (non-bank lending). Loan-financed residential transactions are the sum of transactions where the credit is originated by banks, credit unions, non-bank financial intermediaries, and other creditors (for example, developers or seller-financed). Non-bank lending is defined as the share of mortgages originated by financial intermediaries other than banks and credit unions. This includes mortgage lenders, finance companies, lending companies, insurers, foreclosure companies, and subprime lenders. Thus, the total originated loan amount in a quarter can be partitioned into the loan shares originated by banks and credit unions, non-bank financial intermediaries, and other lenders: $L_{i, q}=B_{i, q}+N B_{i, q}+O_{i, q}$, weighted by the loan amount. 
Definition 7 (conforming loans). Focusing on real estate purchases with mortgages, transaction-level detailed data allow us to classify loans into the conforming loans category. These are mortgages that meet the criteria established by the Federal Housing Finance Agency to be eligible for Fannie Mae or Freddie Mac to purchase the loan from the bank once it was originated. The main criterion concerns a limit on the loan amount, which we approximate at $\$ 500,000$.

Definition 8 (foreclosed sales). To determine the foreclosed sales, we use Zillow's monthly data on the percentage share of sales in which the bank took possession of the property following a foreclosure within the prior year.

\section{Transaction-Level Data}

The ZTRAX database covers more than 20,000 zip codes, with almost 90 million transactions after data cleaning, spanning over the 1998-2018 period. The analysis focuses on sale transactions, and 40 states with reliable, representative data are considered. Refinancing, home equity loans, reverse mortgages, and loan modifications were excluded from our sample, to ensure consistency in transactions. Table 1 presents the summary statistics of the quarterly data aggregated at the zip code level.

Likewise, the descriptive statistics of the transaction-level data are provided in Annex Table 1 for all purchases (left panel) and for credit-financed sales only (right panel). The overall transaction sample totals about 88 million observations, out of which nearly 50 million were loan-financed. The mean and median property sale price is slightly lower in the overall sample than in the credit-financed one. They stand at about $\$ 265,000$ and $\$ 195,000$, respectively. Moreover, a typical loan amounts to $\$ 215,000$, while the LTV ratio averages 84 percent. Finally, the LTV ratio of loans originated by banks is, on average, lower by about 3.5 percentage points than the ratio of loans originated by non-bank financial intermediaries.

The transaction-level data were aggregated at the zip code level, with the main analysis conducted at quarterly frequency, to match the house price indices computed by Zillow and to smooth out excess volatility from monthly data. The main advantage of using the ZTRAX transaction-level data is that it provides granular information about properties, transactions, buyers, sellers, lenders, and loan characteristics. The main disadvantage is that the information content varies substantially across states and time ${ }^{7}$.

Various data features allow us to classify lenders as banks or non-banks and construct the share of shadow bank lending activity when mortgage loans are concerned. Second, we are able to identify different types of non-traditional investors in the residential housing market based on transaction and property characteristics such as purchase type (mortgage or cash), property use, buyer type and origin, property address, mortgage type (for example, conventional), time between sale and resale of the same property, and so on. Third, we extract information about

\footnotetext{
${ }^{7}$ In our analysis, we exclude 10 states for which the number of zip codes and transactions are not representative, that is, Alaska, Idaho, Indiana, Maryland, Maine, Montana, New Mexico, South Dakota, West Virginia, and Wyoming. In addition, we remove zip codes with fewer than 20 quarterly observations from our sample, which did not provide sufficient information for the assessment of the house price cycles. About 50,000 observations $(\sim 5$ percent $)$ of the data were dropped overall.
} 
the share of conventional mortgages, as well as shares of risky loans such as those with high LTV or adjustable rates (ARMs) in the overall mortgage origination and by each type of lender lending. To construct the instrument, we also extract information about foreclosure sales and loan riskiness from deed records and combine it with other loan data.

\section{House Price Indices}

House price indices are sourced from the Zillow Home Value Index (ZHVI), which is available at the US zip code level. The dataset we use covers 17,216 US zip codes across 40 states over the time period from January 1998 to December 2018. The data coverage is comprehensive and less biased than other sources, with more than 90 percent of the total value of the housing stock and 80 percent of the US population. We also use the Zillow Rent Index (ZRI) data, which have a similar geographical coverage and start in September 2010.

To showcase different types of housing investments, the six panels in Annex Figure 1 depict the evolution of non-primary home buyers over time. The total investor share peaks in 201112, after more than doubling its pre-crisis levels. Compositionally, the share of short-term investors jumps the most in 2008-09, topping 15 percent of total sales volume (panel 2). Cash transactions steadily increased to almost 50 percent of volume over 1998-2013, but subsequently declined to 30 percent by end-2018 (panel 3$)^{8}$. Focusing on corporate cash transactions, a subset of cash purchases involving non-individual buyers, panel 4 shows a similar pattern in the form of short-term investments. Notably, there is substantial heterogeneity across states, with the inter-quartile range of corporate cash share from 5 to 35 percent. This range significantly widens over the years 2008-12. Lastly, panels 5 and 6 depict cross-state distributions of out-of-state buyers and second-home purchases, with the average share of out-of-state buyers increasing steadily since 1998.

Turning to mortgage origination, Annex Figure 2 shows the evolution of different types of lenders. Intuitively, the share of loans originated by non-bank financial intermediaries plunged in 2007-08, in tandem with private securitization (panels 1 and 2). However, this share has gradually increased to more than 50 percent by end-2018 ${ }^{9}$. In comparison to banks, non-bank financial intermediaries originate a higher share of riskier loans such as mortgages with an LTV ratio above 80 or 90 percent, pointing to looser lending standards in this market segment (panels 3 and 4). However, the differences between the two groups of lenders are less pronounced when the share of ARMs is considered (panel 5). As previously established in the literature, the share of originated ARMs is positively associated with short-term interest rates (panel 6).

\footnotetext{
${ }^{8}$ These findings are consistent with Hundtofte and Rantala (2018), who assert that corporate cash purchases of residential real estate were a key loophole in US anti-money-laundering regulations before it was fixed in 2016.

${ }^{9}$ Annex Figure 3 highlights the geographical dispersion of shadow banking origination across US counties in 2008 and 2018. There are stark differences between the two years, reflecting the substantial increase in non-bank financial intermediation over the past decade. This is particularly evident on the West Coast.
} 


\section{Methodology}

\section{A. Timing-Assumption Approach}

First, we investigate the relationship between different types of non-primary home investment demand and residential house price cycles. The main specification is estimated using panel data with fixed effects in which we rely on a classic timing assumption ${ }^{10}$ :

$$
\begin{aligned}
\Delta \ln (h p)_{i, t}= & \alpha_{0}+\alpha_{h} \Delta \ln (h p)_{i, t-1}+\beta_{1} * S H I_{i, t-1}+\theta_{1} * S H I_{i, t-1} * I_{t}^{\text {Crisis }}+\beta_{2} \\
& * S T I_{i, t-1}+\theta_{2} * S T I_{i, t-1} * I_{t}^{\text {Crisis }}+\beta_{3} * L L C_{i, t-h}+\theta_{3} * L L C_{i, t-h} \\
& * I_{t}^{\text {Crisis }}+\beta_{4} * O S B_{i, t-h}+\theta_{4} * O S B_{i, t-h} * I_{t}^{\text {Crisis }}+v_{i}+\xi_{t}+\gamma_{i, t}+\epsilon_{i, t}
\end{aligned}
$$

where $\Delta \ln (h p)_{i t}$ is the quarterly log change in the median house value of each zip code $^{11}$. For each quarter $\mathrm{t}, S H I_{i, t}$ denotes the zip code-level share of second home buyers, $S T I_{i, t}$ denotes the zip code-level share of within-year resales (short-term buyers), $L L C_{i, t}$ is the share of transactions by corporate cash within the zip code, and $O S B_{i, t}$ is the share of transactions by out-of-state buyers. $I_{t}^{\text {Crisis }}$ is an indicator variable equal to 1 during GFC years (2007 - 2009). The regressors are lagged one quarter. All regressions control for zip code and quarter-fixed effects. Standard errors are clustered at the zip code level in most regressions.

We conduct a battery of robustness checks. For instance, we additionally control for state-year fixed effects, which absorb time-varying features at the state level, such as the legislation, economic fundamentals (for example, income per capita), and potential differences stemming from banking regulation. Furthermore, standard errors are clustered at the state level to potentially deal with correlation structures due to transaction-level data, which are reported by state. In addition, the baseline results are rerun with the dependent variable being replaced by year-on-year changes in prices instead of quarterly changes, to deal with potential seasonality issues.

Second, the following quarterly regression is considered to better understand the role of credit supply for the evolution of house prices over the cycle:

$$
\begin{aligned}
\Delta \ln (h p)_{i, t}= & \alpha_{0}+\alpha_{h} \Delta \ln (h p)_{i, t-1}+\beta_{1} * \operatorname{NonBank}_{i, t-1}+\theta_{h}^{1} * \text { NonBank }_{i, t-1} \\
& * I_{t}^{\text {Crisis }}+\beta_{2} * \operatorname{LTV}_{i, t-1}+\theta_{h}^{2} * \operatorname{LTV}_{i, t-1} * I_{t}^{\text {Crisis }}+\beta_{3} * \text { ARM }_{i, t-1} \\
& +\theta_{h}^{3} * \text { ARM }_{i, t-1} * I_{t}^{\text {Crisis }}+v_{i}+\xi_{t}+\gamma_{i, t}+\epsilon_{i t}
\end{aligned}
$$

where $\Delta \ln (h p)_{i t}$ is the quarterly log change in the median house value in each zip code. $A R M_{i, t}$ denotes the share of adjustable rate mortgages within the zip code, NonBank $k_{i, t}$ is the share of mortgages issued by non-bank lenders, and $L T V_{i, t}$ is the share of mortgages with an LTV higher than 90 percent. Similar to equation (1), $I_{t}^{\text {Crisis }}$ is the crisis indicator variable equal to 1 during the GFC. All regressions control for zip code and quarter fixed effects, while

\footnotetext{
${ }^{10}$ Using the timing-assumption approach, the fixed-effect panel estimations cover the 1998Q1-2018Q4 period.

${ }^{11}$ Additionally, we run the same analysis where changes on rental indices are considered as the dependent variable.
} 
for robustness several regressions include state-year fixed effects as well. ${ }^{12}$ Standard errors are clustered at the zip code level, Federal Information Processing Standards (FIPS) level and state level, respectively.

Third, in order to assess the relationship between non-bank financial intermediation and riskier loans such as mortgages originated with weaker lending standards, we estimate the following quarterly regression specification at the zip code-level:

$$
Y_{i, t}=\alpha_{0}+\delta * Y_{i, t-1}+\beta_{1} * \operatorname{NonBank}_{i, t}+v_{i}+\xi_{t}+\gamma_{i, t}+\epsilon_{i, t}
$$

where the dependent variable $Y_{i, t}$ denotes the mean LTV, the share of LTV above 90 percent, and the share of ARMs, respectively. NonBank $k_{i, t}$ denotes the share of mortgages issued by non-bank financial lenders within each zip code. All regressions control for zip code and quarter fixed effects, and one-quarter lagged dependent variable. Additionally, year-state fixed effects were included in some robustness specifications, while standard errors were clustered at the state level in all specifications.

\section{B. Instrumental Variable Approach}

The methodology discussed above allows us to shed light on the relationships between the different measures of non-primary home investment demand and house prices over the boombust cycle. However, these correlations may also be driven in part by reverse causality issues. To disentangle the causal effects of different sorts of non-traditional investments on the house price cycle, as well as on the changes in rents, we employ an instrumental variable analysis.

Immediately following the financial crisis, the two main GSEs operating in the residential real estate market, Fannie Mae and Freddie Mac, implemented the First Look program with the objective of increasing neighborhood stability and encouraging homeownership among households. The First Look program gave a window of opportunity of 15 to 20 days ${ }^{13}$ to household homeowners to bid on for-sale properties that had been foreclosed and for which the mortgage was owned by either of the two GSEs. The program, started in August 2009 by Fannie Mae and Freddie Mac, implemented a similar strategy in September 2010. This program, by definition, directly impacted the composition of the buyer pool, especially in those areas where Fannie and Freddie owned a large fraction of the mortgages on foreclosed properties. Therefore, it provides a quasi-natural experiment to shed light on the question of the impact of non-primary home demand on the housing price cycle ${ }^{14}$.

\footnotetext{
${ }^{12}$ Additionally, the application of the system GMM proposed by Arellano and Bond (1991) shows consistently robust results (available upon request).

${ }^{13}$ Later extended to 30 days in some areas.

14 The approach using this instrument is similar to Lambie-Hanson and others (2019), who also employ this instrument using transaction level data in 20 cities to study the impact of institutional investors on the housing market. We expand on their findings by using a more comprehensive dataset covering 40 states and applying it to our constructed measures of non-primary home investment demand, including second-home buyers and corporations purchasing properties in cash.
} 
When a mortgage owned by either GSE defaults, an auction follows allowing potential buyers to bid for the property. If no submitted bid covers the loan amount, then the house becomes real estate owned (REO), meaning that its title is transferred to the GSE, which then puts it on the market for sale. Most houses with defaulting mortgages end up as REOs.

To construct our instrument, we start by measuring the share of recently foreclosed properties among the total sales in a zip code-quarter observation unit. We obtain this information from the Zillow Research Data public website, which contains monthly data on the percentage share of sold properties that were foreclosed within the prior year and that were bank owned.

Among those foreclosure sales, the properties concerned with the First Look program were only those where the mortgage was owned by Fannie Mae and Freddie Mac. To be purchased by the GSEs, a mortgage must satisfy a number of conditions, among which the main restriction is on the loan amount, which cannot exceed a limit set by the Federal Housing Finance Agency (FHFA) ${ }^{15}$. We use our transaction level data to compute a proxy for the share of conforming loans in a zip code identified as purchases where the loan amount does not exceed $\$ 500,000$. Our zip code-quarter level instrument is then the share of foreclosure sales times the share of conforming loans. Our hypothesis is that areas where this measure is high, denoting a higher share of First Look properties, we should find a lower share of non-owneroccupied homes following the program implementation, as well lower speculative activity. We use this instrument in a two-stage least square specification to identify the causal effect of our various measures of non-primary home demand on the housing price cycle. The identifying assumption is that the share of First Look properties affected prices only through the composition of the buyer pool.

To examine the impact of the First Look program on our measures of second home buyers and corporate buyers in cash, we estimate the following specification at the zip code level: ${ }^{16}$

$$
Y_{i, t}=\alpha_{0}+\beta_{0} Y_{i, t-1}+\beta_{1} * F L_{i, t-1}+\beta_{2} * \text { Post }_{F L} * F L_{i, t-1}+v_{i}+\xi_{t}+\epsilon_{i, t}
$$

where the dependent variable $\mathrm{Y}_{\mathrm{I}, \mathrm{t}}$ denotes the share of second-home buyers or the share of corporate cash buyers. Post $\mathrm{FL}_{\mathrm{FL}}$ is a dummy variable denoting the period after the First Look program started, equal to 1 after 2009Q3 and 0 otherwise. The estimations use one-year moving average shares and the independent variables are lagged by one quarter. All regressions control for zip code and quarter-fixed effects.

We use the share of properties affected by the First Look program as an instrument to investigate the causal effect of non-primary home demand on house prices. The exclusion restriction in this analysis requires that the First Look program affected prices only through the composition of the buyer pool. The instrument variable is used consecutively on the share of second-home buyers (or non-owner occupiers) and the share of corporate cash buyers, which

\footnotetext{
${ }^{15}$ This limit on conforming loan size is updated annually and can be different from one county to another.

${ }^{16}$ Due to foreclosure data availability, the estimations with the instrumental variables cover the 2008Q1-2018Q4 period (44 quarters).
} 
are the two main measures of non-primary home investment demand that we expect to be affected by the program. The two-stage least-square specification is estimated as follows:

$$
\begin{aligned}
\Delta \ln (h p)_{i, t}= & \alpha_{0}+\alpha_{h} \Delta \ln (h p)_{i, t-h}+\beta_{1} * \overline{S H I}_{i, t-h}+\beta_{2} * \overline{L L C}_{i, t-h}+v_{i}+\xi_{t} \\
& +\gamma_{i, t}+\epsilon_{i, t}
\end{aligned}
$$

where $\Delta \ln (\mathrm{hp})_{\text {it }}$ is the quarterly log change in the median house value of each zip code. For each quarter $t, \overline{\mathrm{SHI}}_{\mathrm{I}, \mathrm{t}}$ denotes the instrumented share of second-home investors in each zip code, and $\overline{\mathrm{LLC}}_{\mathrm{I}, \mathrm{t}}$ is the instrumented share of cash purchases by institutional investors within each zip code. The estimations use one-year moving average shares and the independent variables are lagged by one quarter. All regressions control for zip code and quarter-fixed effects. 


\section{RESUlts}

Using a traditional timing assumption, the relationship between non-primary buyers and the housing cycle is initially presented, followed by a thorough investigation using an instrumental variable approach, which reinforces the overall analysis. In addition, we shed light on the effects of the non-primary buyers on the rental market.

\section{A. House Prices and Non-Primary Home Buyers}

Our baseline results are presented in Table 2.A, which links quarterly changes in house prices (the dependent variable) to various types of non-primary home buyers. To unveil potential nonlinearities, we introduce a dummy variable capturing the bust period, namely 2007Q1 to 2009Q4. Given that the typical endogeneity issue in testing the impact of non-primary housing demand could be at play, all independent variables were lagged by one quarter. Thus, in testing the impact on the housing cycle, we rely on a timing assumption that unknown future changes in house prices do not affect the fraction of non-traditional investors today.

Column 2 reports the regression coefficients when second-home buyers are considered, accounting for nonlinearities over the housing cycle. This regression indicates that an increase in the fraction of second-home buyers has a positive and significant effect on prices during boom times. The point estimate in column 2 implies that a one standard deviation increase in the share of second-home buyers strengthens the booming house prices by about 0.3 percent. At the same time, non-owner-occupied purchases are found negatively and significantly associated with house prices during the bust period. In general, there is a substantial asymmetry in terms of magnitudes, with much stronger effects during the bust period than in booms. In economic terms, a rise in the share of second-home buyers by one standard deviation is associated with a 2.36 percent reduction (the sum of the two coefficients) in house prices during the GFC. These magnitudes stand up to various robustness checks (columns 9-11).

Column 4 reports the coefficients when within-year resale activity is considered, considering potential nonlinearities. This regression indicates that an increase in the share of short-term investors is significantly associated with the housing cycle, amplifying the boom and bust. The magnitude of the effects on the housing cycle is comparable with those of second-home buyers during booms. When the housing market deteriorates, an increase in the share of short-term investors by one standard deviation reduces house prices by about 1.5 percent. The robustness checks confirm the consistency of these results, even when controlling for state-time fixed effects and clustering at the state level (column 12).

The relationship between the share of cash corporate transactions and the housing cycle is presented in column 6 . The results reveal a negative and significant association involving corporate cash transactions throughout the cycle, although the effects seem much weaker. In addition, these findings seem less robust when applied to more stringent specifications (columns 11 and 12). In contrast, a higher share of purchases by out-of-state buyers is found to be significantly and positively associated with house prices, especially during bust periods (columns 9, 10, and 12). In other words, out-of-state buyers prop up prices during the recession, potentially reflecting less focus on short-term capital returns. However, in terms of magnitude, 
the effects of out-of-state buyers are much weaker than other non-primary house buyers. These findings corroborate those by Chinco and Mayer (2016).

Using the same timing approach, Table 2.B presents our analysis where changes in rental price indices are concerned ${ }^{17}$. The analysis reveals several interesting and novel results. Consistent across all specifications, the share of non-primary home buyers is negatively associated with changes in rents. For instance, a one standard deviation increase in the share of second-home buyers or short-term investors is associated with about 0.4 percent decline in rental indices over the following quarter. In contrast, the increase in the share of out-of-state buyers has half of this magnitude, while the relationship involving corporate cash transactions is not found statistically significant.

\section{B. The Role of Non-Bank Lending}

Next, relying on the same timing assumption, we present the regression estimates by splitting the zip codes into distinct groups based on the importance of shadow bank lending (non-bank financial intermediation). The hypothesis here is that areas with a higher share of shadow bank lending are more prone to these investments and thus the amplification of the housing cycle. To rank all zip codes, the average share of non-bank lending for each area is considered. High and Low groups are defined as the top and bottom quartile, respectively. For instance, areas in the High group have, on average, a share of shadow bank lending of about 65 percent, while areas in the Low group have only 20 percent. This split allows us to contrast the effects of nontraditional investments on the housing cycle in areas with high and low shadow banking activity.

Table 3 displays the estimated regressions where areas are split based on shadow banking activity. Similar to the focus of the regressions presented in Table 2.A, we are interested in gauging the relationship between non-primary buyers and the housing cycle, exploiting the heterogeneity of shadow bank activity across zip codes. The odd columns present the regressions corresponding to the High group areas, while the even columns present Low group areas. In columns 1 and 2, the effects of second-home buyers are contrasted. For instance, in areas with a higher share of shadow bank lending, a one standard deviation growth in the fraction of second-home buyers leads to about a 0.5 percent increase in house prices over the following quarter during boom times. Conversely, the effects are not found significant during booms in the Low group areas (column 2). The point estimate in Column 1 implies that a one standard deviation rise in the fraction of second-home buyers in High group areas is associated with about a 5 percent slump in house prices during the bust. At the same time, the effects in areas dominated by bank mortgage lending (Low group) are found significant during the bust, but with a much weaker magnitude than in areas with more shadow bank origination. In economic terms, a one standard deviation growth in the fraction of second-home buyers is followed by around 1.3 percent fall in house prices in Low group areas. Robustness checks presented in columns $9-14$ broadly confirm these results.

\footnotetext{
${ }^{17}$ Due to limited data availability, this analysis covers the period after 2010 . The main constraint is the availability of rental indices at the zip code-level before that period.
} 
Turning now to short-term investors (columns 3 and 4), our findings suggest that the relationship between within-year resales and house prices is much stronger in High group areas with a higher share of shadow bank intermediation than in the Low group. A one standard deviation increase in the share of short-term investors in the High group areas is subsequently associated with about 1 percent price growth during housing booms (column 3 ). At the same time, the effects are only about 0.25 percent in the Low group areas. When house price busts are considered, the rise of short-term investment share in total purchases by 1 percent is followed by a 0.8 percent drop in house prices in both High and Low group areas.

Finally, the patterns are less clear for corporate cash investors and out-of-state buyers, when these splits are considered, (except as illustrated in columns 11 and 12, that is, with state-time fixed effects). In these estimations, both corporate cash buyers and out-of-state buyers are significantly associated with the housing cycle only for the High group. However, the point estimates are much weaker than for the other non-traditional investors. Consistent with the previous findings (in Table 2.A), out-of-state buyers are propping up the housing markets when prices fall. In economic terms, a one standard deviation increase in the share of out-of-state buyers leads to 0.5 percent rise in house prices during the GFC.

\section{Zooming in: Non-Bank Lending and Riskier Mortgages}

To further our understanding, we shed some light on the relationship between the non-bank lending and house prices presented in Table 4. The main findings suggest that an increase in new originations by shadow banks is followed by an amplification of the housing cycle, similar to purchase activities involving non-traditional buyers such as second-home investors and short-term buyers. In economic terms, a one standard deviation rise in the fraction of shadow bank lending is associated with less than 0.1 percent house price growth during boom times and about 0.25 percent decline in house prices during the bust. Likewise, the link between the share of ARM loans and house prices is considered in Columns 5-6. Interestingly, this relationship is found to be negative and significant throughout the cycle, but with a substantially stronger intensity during the bust. The point estimates imply that a one standard deviation increase in the share of ARMs is accompanied by a 0.2 percent drop in house prices over the following quarter, during the bust.

Finally, Table 5 establishes the link between shadow bank activity and the riskier mortgages. For instance, columns 2, 4, and 6 suggest a robustly significant and positive relationship between shadow bank lending and the share of mortgages with an LTV ratio above 90 percent. In the same vein, columns 7 and 8 show a significant and negative association between shadow banking and ARMs.

\section{Instrumental Variable Analysis}

The results above establish strongly significant correlations between our measures of nonprimary home demand and local house prices. In particular, they indicate that market timing investors, as proxied by the share short-term (within-year) resales in a zip code area, and second-home purchases are associated with an amplified boom-bust price cycle. However, these results may suffer from endogeneity issues. For example, a plant opening in a given area may spur local economic activity, driving up local demand and house prices, while at the same 
time attracting greater investments, including in the real estate sector. To tackle this problem, we use an instrumental variable approach, exploiting the First Look program that affected the composition of the buyer pool in the US residential real estate markets in a plausibly exogenous way.

In Figure 2, we rank zip codes each quarter by the share of foreclosure properties in total sales (Panel 1) and our measure of the share of properties affected by the First Look program (Panel 2 ). The charts present the time series of the median, $75^{\text {th }}$, and $90^{\text {th }}$ percentile zip codes quarterly over 2008Q1-2018Q4. The share of foreclosure sales peaks in 2009-10 and then decreases gradually after 2013. The share of First Look properties follows a similar pattern. Panels 3 and 4 of Figure 2 show the geographical distribution of our data on foreclosure sales and the instrument variable. It depicts a relatively wide coverage of states, with higher percentage shares in the coastal areas and particularly in the Southwestern states.

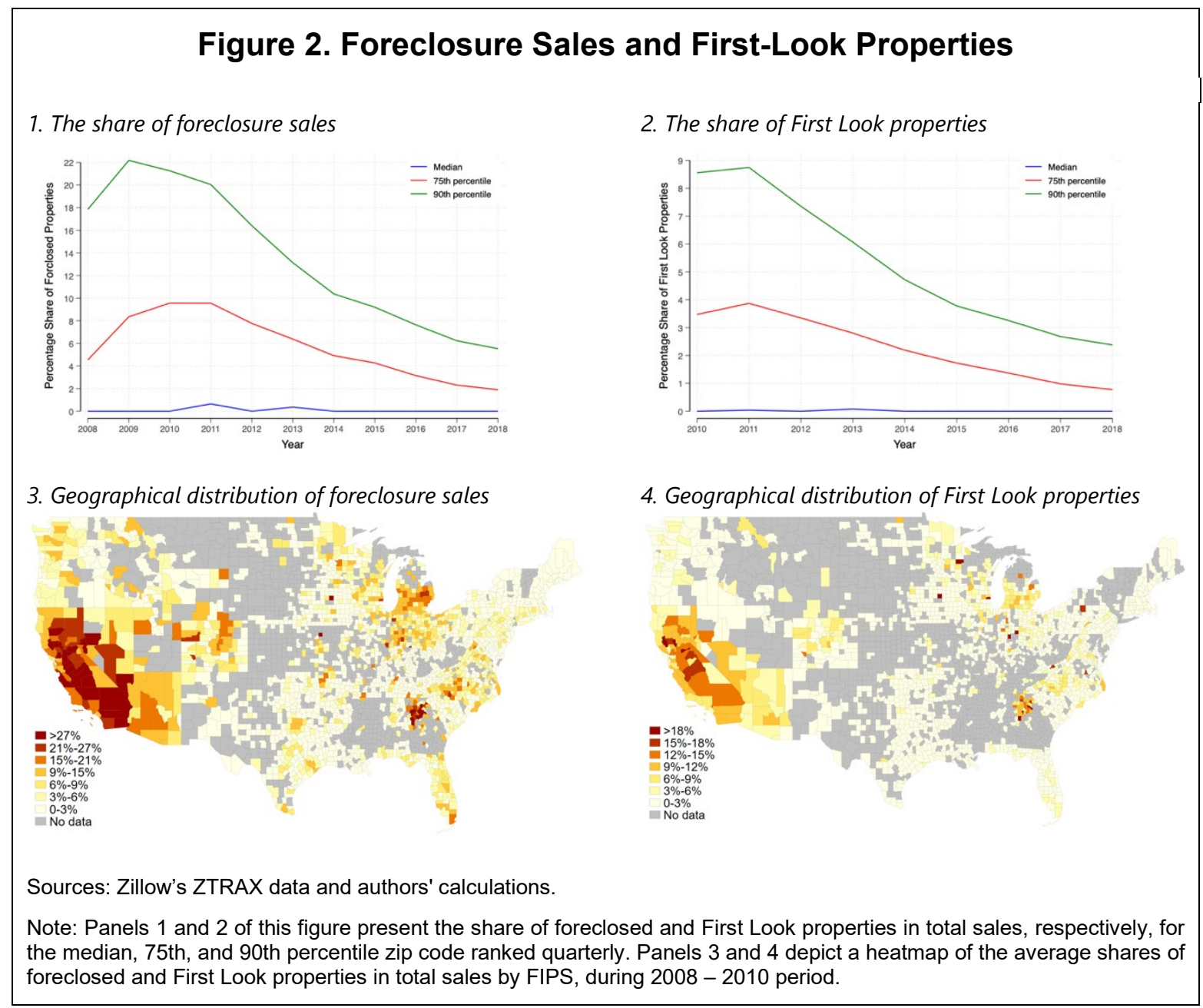

Next, we study the direct impact of the First Look program on our measures of speculative activity. In particular, we investigate whether the program had an effect on the share of secondhome buyers and corporate buyers in cash. We specifically focus on these two measures because the program was designed to affect non-owner-occupier investment demand. We start by sorting zip codes into quintiles by the share of First Look properties as measured by our 
instrument, for every quarter, and plot the time series of the shares of second-home buyers and corporate buyers in cash in Figure 3, for both the highest and lowest quintiles, sorted by exposure to the First Look program.

In panel 1, we show that while the trends were relatively parallel prior to the enactment of the program in August 2009, areas in the highest quintile of exposure saw a drop in the share of second-home buys, when compared with the lowest quintile areas. This finding is consistent with the purpose of the program and provides graphical evidence in support of a negative effect of the First Look program on the share of second -home buys in the most exposed areas. Panel 2 of Figure 3 follows a similar methodology to showcase the impact of the First Look program on corporate buyers in cash. We find evidence in support of the parallel trend assumption prior to the program, and while the post-program effect is less evident than that on second-home demand, we see a steeper decline in corporate cash demand in the zip codes of highest exposure to the First Look program.

We examine the impact of the First Look program on non-primary home demand more formally by estimating linear regressions around the time of the program implementation, the results are reported in Table 6. Consistent with the graphical evidence shown in Figure 3 we find strongly negative and significant correlations between the share of properties affected by the First Look program in a zip code area, and the share of buys that represent non-primary home demand of household owner-occupiers. Furthermore, this relationship is present only after the program started, as evidenced by the coefficient on the interaction term of post-First Look with the measure of investment activity. While the parallel trends assumption is verified graphically in Figure 3, the positive correlation between the share of First Look properties and non-primary home buyers prior to the enactment of the program indicates a potentially higher presence of investment activity ex-ante in the targeted areas. The key insight is that the decline in non-primary home buyer demand corresponds closely with the program and is most prevalent in the most affected areas. These results support the idea that the program had an impact on the composition of the buyer pool in the most affected areas, as originally intended and designed for by the GSEs. Specifically, areas with a high exposure to the First Look initiative, as measured by a higher share of foreclosed properties with conforming mortgages, saw a disproportionate decrease in second-home buys and purchases from corporate buyers in cash following the enactment of the program.

Finally, we directly examine the causal effect of non-primary-home demand on house prices by exploiting the setting described above and using the share of properties within a zip code that were affected by the First Look program as an instrumental variable in a two-stage least square regressions framework. ${ }^{18}$ The results of the second stage are presented in Table 7, with the share of second-home buyers being the instrumented variable in columns 1-3, while corporate transactions made in cash represent the variable instrumented in columns 4-6.

Validating our OLS estimations results reported above, the instrumented measure of second home buyers is found to significantly and positively affect house prices. In particular, a one standard deviation expansion in the share of second home buyers increased house prices on

${ }^{18} \mathrm{~F}$-statistics of the IV's first stage, reported in Tables 7 and 8 , confirm the validity of our instrument. 
average by 66 basis points per quarter (column 3). We also find evidence that corporate purchases in cash, which in part represents anonymity seeking capital (Hundtofte and Rantala 2018), raised house prices by about 9 basis points per quarter on average for each standard deviation increase. These results provide causal support to the claim that second home demand played a significant role in driving up prices during the post-crisis recovery. We also find evidence in support of the role played by institutional buyers in cash, which is consistent with the findings in Lambie-Hanson and others (2019).

We run a similar analysis on the causal impact of non-primary home investment demand on quarterly changes in the residential rental prices at the zip code level. Table 8 reports the results of estimations taking the quarterly percentage changes in the Zillow Rental Index for the zip code area as the dependent variable. We find that an increase in investment demand, as proxied by the share of second home and corporate purchases in cash, helped decelerate the growth in the rental index in the most affected areas. This evidence is consistent with a buy-to-rent logic of investment demand whereby investors purchase properties and subsequently increase the supply in the market for rentals.

\section{Figure 3. First Look Program and Non-Primary Home Demand}

1. Share of second-home buyers

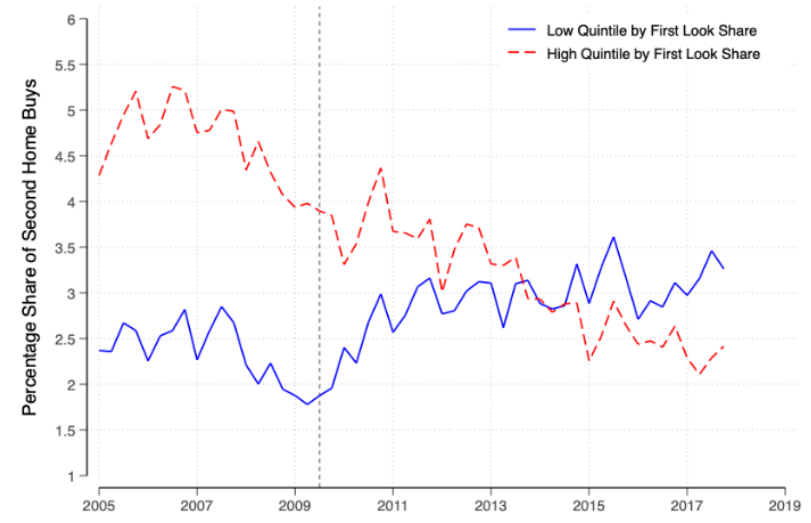

2. Share of corporate purchases in cash

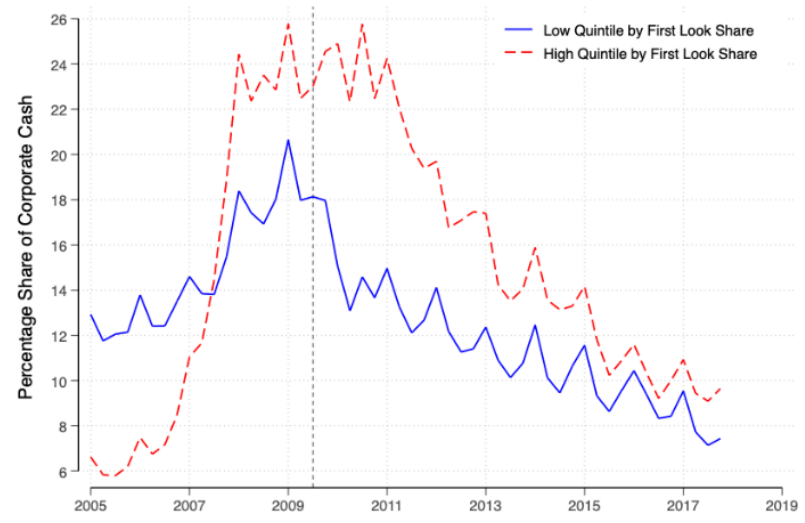

Sources: Zillow's ZTRAX data and authors' calculations.

Note: This figure presents the time series of the share of second-home buys (panel 1) and purchases made by corporations in cash (panel 2 ) in total sales for the highest and lowest quintile zip codes ranked every quarter by the share of First Look properties. Due to data availability of foreclosure sales, zip codes in 2005-09 are ranked based on the average share of First Look properties over 2010. 


\section{Conclusion}

This paper makes several contributions to our understanding of housing and mortgage markets by examining the role of real estate investors. Using transaction-level data, we study the relationship between different types of non-primary home buyers and house price cycles. In addition, we uncover novel evidence concerning the causal impact of non-primary home buyers on rents.

Relying on detailed transaction-level information, we document four types of non-traditional housing buyers. Collectively, our evidence suggests that housing transactions involving corporate cash buyers and short-term investors surged in the aftermath of the GFC, helping to prop up housing market liquidity. At the same time, out-of-state buyers and transactions involving non-primary home buyers dropped and slowly recovered in the aftermath of the crisis as market confidence was restored. We show that shadow banking origination activity has steadily rebounded in the aftermath of the mortgage crisis, as evidenced in the existing literature. Historically, shadow bank lending has been associated with lower lending standards (for example, high LTV mortgages).

Our empirical analysis assesses the effects of non-traditional buyers on the housing cycle. We systematically find that second-home buyers and short-term investors are amplifying the housing cycle, both during booms and busts. In contrast, out-of-state buyers prop up prices during the bust. Combining non-primary home demand with credit supply information, our findings suggest that areas with a higher share of shadow banking originations are disproportionately affected by non-traditional buyers. During the GFC, the sensitivity of house prices to second-home buyers in areas with higher shadow bank lending activity is found to be four times larger than the sensitivity in areas dominated by banks.

To address potential endogeneity issues, we rely on an instrumental variable approach that exploits the zip code heterogeneity of exposures to the First Look program, implemented by the two main GSEs after the financial crisis. Therefore, we find compelling evidence that second-home buyers significantly and positively affect house prices after the implementation of the First Look program. During this period, corporate purchases in cash have an amplifying effect on house prices as well, but of weaker magnitude compared to second-home buyers.

Finally, the effects of non-primary home buyers on rental returns represent a novel finding concerning the role of non-traditional investors in the housing market. Increases in second home investments and corporate cash purchases reduce the rental index in the most affected areas.

Our findings have several policy implications. Importantly, macroprudential, monetary, and fiscal policies are central levers to mitigate excessive house price and rent appreciation through various transmission channels such as credit availability, housing demand, and balance sheet effects. In particular, our results make a strong case for the development of a complete macroprudential policy framework for non-bank financial intermediaries, such as expanding the scope of the macroprudential toolkit to address the emerging risks and limit policy leakages (Adrian and Ashcraft, 2012; Claessens, 2015). 
Table 1. Summary Statistics

(zip code level; quarterly frequency)

\begin{tabular}{lrrrrrr}
\hline & \multicolumn{7}{c}{ Zipcode-level (quarterly frequency) } \\
\hline & \multicolumn{1}{c}{$\mathrm{N}$} & \multicolumn{1}{c}{ mean } & \multicolumn{1}{c}{ sd } & min & \multicolumn{1}{c}{ p50 } & max \\
\cline { 2 - 7 } & & & & & & \\
$\Delta$ price (q-on-q, \%) & $1,046,854$ & 0.7437 & 2.1114 & -14.2525 & 0.8173 & 12.4 \\
$\Delta$ price (y-on-y, \%) & $1,023,660$ & 2.941 & 7.4883 & -51.2561 & 3.2389 & 38.5 \\
$\Delta$ rent (q-on-q, \%) & 332,854 & 0.4469 & 2.6455 & -35.7366 & 0.4623 & 26.2 \\
Cash (share, \%) & $1,154,922$ & 48.9122 & 37.1178 & 0 & 38.4853 & 100 \\
Mortgage (share, \%) & $1,154,922$ & 51.0878 & 37.1178 & 0 & 61.5147 & 100 \\
Second Home (share, \%) & $1,141,653$ & 1.5001 & 4.7898 & 0 & 0 & 40.2 \\
Within-year Resale (share, \%) & $1,145,061$ & 6.0864 & 9.011 & 0 & 3.0151 & 65.1 \\
Corporate Cash (share, \%) & $1,154,922$ & 13.4638 & 23.4881 & 0 & 3.7074 & 100 \\
Out-of-State Buyers (share, \%) & $1,154,922$ & 5.1341 & 14.443 & 0 & 0 & 100 \\
Bank Lender (share, \%) & 729,496 & 55.01 & 28.97 & 0 & 52.39 & 100 \\
NonBank Lender (share, \%) & 729,496 & 44.9858 & 28.9677 & 0 & 47.6082 & 100 \\
LTV (mean) & 824,963 & 0.8829 & 0.1138 & 0 & 0.9 & 1.5 \\
LTV > 90\% & 831,046 & 49.363 & 31.2893 & 0 & 49.9345 & 100 \\
Float Rate (share, \%) & 723,871 & 27.0979 & 35.6142 & 0 & 8.5712 & 100 \\
Conforming Loans (share, \%) & 831,046 & 31.81 & 34.1 & 0 & 21.88 & 100 \\
Foreclosed Loans (share, \%) & 623,509 & 4.6465 & 8.8612 & 0 & 0 & 100 \\
\hline
\end{tabular}

Sources: Zillow's ZTRAX data and authors' calculations.

Note: "N" denotes number of observations and "sd" is the standard deviation; "min," "p50," and "max" denote the minimum, the median, and the maximum, respectively. 


\begin{tabular}{|c|c|c|c|c|c|c|c|c|c|c|c|c|}
\hline & (1) & (2) & (3) & (4) & (5) & (6) & $(7)$ & (8) & (9) & (10) & (11) & (12) \\
\hline & \multicolumn{12}{|c|}{ House prices $(\Delta \%$, qoq) } \\
\hline House prices (lag, $\Delta \%)$ & $\begin{array}{c}0.6815^{* * *} \\
(0.0019)\end{array}$ & $\begin{array}{c}0.6784^{* * *} \\
(0.0019)\end{array}$ & $\begin{array}{c}0.6815^{* * *} \\
(0.0019)\end{array}$ & $\begin{array}{c}0.6758 * * * \\
(0.0018)\end{array}$ & $\begin{array}{c}0.6803 * * * \\
(0.0019)\end{array}$ & $\begin{array}{c}0.6790 * * * \\
(0.0019)\end{array}$ & $\begin{array}{c}0.6807 * * * \\
(0.0019)\end{array}$ & $\begin{array}{c}0.6807^{* * *} \\
(0.0019)\end{array}$ & $\begin{array}{c}0.6731^{* * *} \\
(0.0018)\end{array}$ & $\begin{array}{c}0.6731^{* * *} \\
(0.0089)\end{array}$ & $\begin{array}{c}0.6731^{* * *} \\
(0.0272)\end{array}$ & $\begin{array}{c}0.5480 * * * \\
(0.0209)\end{array}$ \\
\hline Second Home (lag, share of total) & $\begin{array}{c}-0.0025^{* * *} \\
(0.0004)\end{array}$ & $\begin{array}{c}0.0030^{* * *} \\
(0.0004)\end{array}$ & & & & & & & $\begin{array}{c}0.0029 * * * \\
(0.0004)\end{array}$ & $\begin{array}{c}0.0029 * * * \\
(0.0008)\end{array}$ & $\begin{array}{c}0.0029 * * * \\
(0.0010)\end{array}$ & $\begin{array}{c}-0.0006 \\
(0.0009)\end{array}$ \\
\hline Crisis \# Second Home (lag) & & $\begin{array}{c}-0.0266^{* * *} \\
(0.0010)\end{array}$ & & & & & & & $\begin{array}{c}-0.0265^{* * *} \\
(0.0010)\end{array}$ & $\begin{array}{c}-0.0265^{* * *} \\
(0.0029)\end{array}$ & $\begin{array}{c}-0.0265^{* *} \\
(0.0099)\end{array}$ & $\begin{array}{c}0.0004 \\
(0.0022)\end{array}$ \\
\hline Short-term Buyers (lag, share of total) & & & $\begin{array}{c}0.0003 \\
(0.0002)\end{array}$ & $\begin{array}{c}0.0031^{* * *} \\
(0.0002)\end{array}$ & & & & & $\begin{array}{c}0.0032^{* * *} \\
(0.0002)\end{array}$ & $\begin{array}{c}0.0032^{* * *} \\
(0.0004)\end{array}$ & $\begin{array}{c}0.0032^{* *} \\
(0.0013)\end{array}$ & $\begin{array}{l}0.0010^{*} \\
(0.0005)\end{array}$ \\
\hline Crisis \# Short-term Buyers (lag) & & & & $\begin{array}{c}-0.0182 * * * \\
(0.0006)\end{array}$ & & & & & $\begin{array}{c}-0.0176 * * * \\
(0.0006)\end{array}$ & $\begin{array}{c}-0.0176 * * * \\
(0.0022)\end{array}$ & $\begin{array}{c}-0.0176 * * * \\
(0.0051)\end{array}$ & $\begin{array}{c}-0.0114^{* * *} \\
(0.0040)\end{array}$ \\
\hline Corporate Cash (lag, share of total) & & & & & $\begin{array}{c}-0.0008^{* * *} \\
(0.0001)\end{array}$ & $\begin{array}{c}-0.0004^{* * *} \\
(0.0001)\end{array}$ & & & $\begin{array}{c}-0.0007^{* * *} \\
(0.0001)\end{array}$ & $\begin{array}{c}-0.0007^{* * *} \\
(0.0002)\end{array}$ & $\begin{array}{l}-0.0007 \\
(0.0005)\end{array}$ & $\begin{array}{l}-0.0005 \\
(0.0003)\end{array}$ \\
\hline Crisis \# Corporate Cash (lag) & & & & & & $\begin{array}{c}-0.0042^{* * *} \\
(0.0003)\end{array}$ & & & $\begin{array}{c}-0.0004^{*} \\
(0.0002)\end{array}$ & $\begin{array}{c}-0.0004 \\
(0.0006)\end{array}$ & $\begin{array}{c}-0.0004 \\
(0.0017)\end{array}$ & $\begin{array}{l}-0.0022 \\
(0.0013)\end{array}$ \\
\hline Out-of-state (lag, share of total) & & & & & & & $\begin{array}{c}0.0007^{* * *} \\
(0.0001)\end{array}$ & $\begin{array}{c}0.0007^{* * *} \\
(0.0001)\end{array}$ & $\begin{array}{c}0.0003^{* *} \\
(0.0001)\end{array}$ & $\begin{array}{c}0.0003 \\
(0.0003)\end{array}$ & $\begin{array}{c}0.0003 \\
(0.0004)\end{array}$ & $\begin{array}{c}0.0001 \\
(0.0002)\end{array}$ \\
\hline Crisis \# Out-of-state (lag) & & & & & & & & $\begin{array}{l}-0.0000 \\
(0.0003)\end{array}$ & $\begin{array}{c}0.0016^{* * *} \\
(0.0003)\end{array}$ & $\begin{array}{l}0.0016^{*} \\
(0.0009)\end{array}$ & $\begin{array}{c}0.0016 \\
(0.0016)\end{array}$ & $\begin{array}{c}0.0013^{* *} \\
(0.0005)\end{array}$ \\
\hline Constant & $\begin{array}{c}0.4332^{* * *} \\
(0.0145)\end{array}$ & $\begin{array}{c}0.4345^{* * *} \\
(0.0145)\end{array}$ & $\begin{array}{c}0.4314^{* * *} \\
(0.0146)\end{array}$ & $\begin{array}{c}0.4167^{* * *} \\
(0.0146)\end{array}$ & $\begin{array}{c}0.4412^{* * *} \\
(0.0146)\end{array}$ & $\begin{array}{c}0.4381^{* * *} \\
(0.0146)\end{array}$ & $\begin{array}{c}0.4292^{* * *} \\
(0.0145)\end{array}$ & $\begin{array}{c}0.4292^{* * *} \\
(0.0145)\end{array}$ & $\begin{array}{c}0.4212^{* * *} \\
(0.0146)\end{array}$ & $\begin{array}{c}0.4212^{* * *} \\
(0.0514)\end{array}$ & $\begin{array}{c}0.4212^{* * *} \\
(0.0820)\end{array}$ & $\begin{array}{c}-0.0018 \\
(0.0979)\end{array}$ \\
\hline Quarter FE & Yes & Yes & Yes & Yes & Yes & Yes & Yes & Yes & Yes & Yes & Yes & Yes \\
\hline Zip code FE & Yes & Yes & Yes & Yes & Yes & Yes & Yes & Yes & Yes & Yes & Yes & Yes \\
\hline Year-State FE & No & No & No & No & No & No & No & No & No & No & No & Yes \\
\hline Observations & 990013 & 990013 & 993643 & 993643 & 999970 & 999970 & 999970 & 999970 & 983724 & 983724 & 983724 & 983724 \\
\hline Number of Clusters & 17216 & 17216 & 17214 & 17214 & 17218 & 17218 & 17218 & 17218 & 17212 & 1739 & 40 & 40 \\
\hline Adjusted R-squared & 0.6867 & 0.6872 & 0.6876 & 0.6884 & 0.6864 & 0.6866 & 0.6864 & 0.6864 & 0.6893 & 0.6893 & 0.6893 & 0.7208 \\
\hline $\begin{array}{l}\text { Sources: Zillow's ZTRAX data and } \\
\text { Note: This table presents results fr } \\
\begin{array}{r}\Delta \ln (h p)_{i t}=\alpha_{0}+\alpha_{h} \Delta \ln (h p)_{i, t-h}+ \\
+v_{i}+\xi_{t}+\gamma_{i, t}\end{array} \\
\text { where } \Delta \ln (\mathrm{hp})_{\text {it }} \text { is the quarterly log } \\
\text { denotes the zip code-level share o } \\
\text { transactions by out-of-state buyers } \\
\text { quarter. All regressions control for } \\
\text { regressions (1)-(9), at the FIPS-lev }\end{array}$ & $\begin{array}{l}\text { ors' calculation } \\
\text { stimating regre } \\
S_{H_{i, t-h}+\theta_{1}} \\
\text { nge in the med } \\
\text { in-year resales } \\
\text { is is an indicat } \\
\text { ode-, quarter-fi } \\
\text { (10), and state }\end{array}$ & $\begin{array}{l}\text { ns. } \\
\text { essions arou } \\
* S H I_{i, t-h} * I \\
\text { dian house v } \\
\text { s (flippers), } \\
\text { tor variable e } \\
\text { ixed effects, } \\
\text { e-level in (11 }\end{array}$ & $\begin{array}{l}\text { Und the follon } \\
I^{\text {Crisis }}+\beta_{2} * \text {. } \\
\text { value of each } \\
\text { LLC }_{\mathrm{I}, \mathrm{t}} \text { is the } \mathrm{s} \\
\text { equal to } 1 \mathrm{du} \\
\text {, while last re } \\
\text { 1)-(12). }{ }^{* * *},{ }^{* *}\end{array}$ & $\begin{array}{l}\text { wing main sp } \\
S T B_{i, t-h}+\theta \\
\text { h zip code. } \mathrm{F} \\
\text { share of tran } \\
\text { uring the GF } \\
\text { egression ad } \\
{ }^{*},{ }^{*} \text { indicate }\end{array}$ & $\begin{array}{l}\text { pecification: } \\
\theta_{2} * S T B_{i, t-h} \\
\text { For each qua } \\
\text { nsactions by } \\
\text { C (2007-09) } \\
\text { dds also stat } \\
\text { statistical si }\end{array}$ & $\begin{array}{l} \\
h^{\text {Crisis }}+\beta \\
\text { arter t, } \mathrm{SHI}_{\mathrm{I}, \mathrm{t}} \\
\text { institutional } \\
\text { Estimation } \\
\text { te-year fixed } \\
\text { gnificance at }\end{array}$ & $\begin{array}{l}B_{3} * L L C_{i, t-h} \\
\text { denotes the } \\
\text { investors in } \\
\text { Is concern } 15 \\
\text { effects. Sta } \\
\text { the } 1 \text { perce }\end{array}$ & $\begin{array}{l}\theta_{3} * L L C_{i, t} \\
\text { zip code-le } \\
\text { cash within } \\
98 \mathrm{Q} 1-2018 \\
\text { dard errors } \\
\text { nt, } 5 \text { percen }\end{array}$ & $\begin{array}{l}t-h * I^{\text {Crisis }}+ \\
\text { vel share of } \\
\text { the zip code } \\
\text { BQ4 period. } \\
\text { s are cluster } \\
\text { nt, and } 10 \text { pe }\end{array}$ & $\begin{array}{l}\beta_{4} * O u t_{i, t-h} \\
\text { second-hom } \\
\text {, and Out } \\
\text { Ilt } \mathrm{t} \\
\text { regressor } \\
\text { d at the zip } \\
\text { rcent level, }\end{array}$ & $\begin{array}{l}h+\theta_{4} * \text { Out } \\
\text { ne investors, } \\
\text { is the share } \\
\text { rs are lagged } \\
\text { code-level i } \\
\text { respectively }\end{array}$ & $\begin{array}{l}{ }_{i, t-h} * I^{\text {Crisis }} \\
\operatorname{STB}_{\mathrm{I}, \mathrm{t}} \\
\text { of } \\
\mathrm{d} \text { one } \\
\text { in } \\
\text {. }\end{array}$ \\
\hline
\end{tabular}


Table 2.B. Housing Rent and Non-Primary Home Buyers
(1)
(2)
(3)
$(4)$
(5)
(6)

Rents $(\Delta \%)$

Housing Rent (lag, $\Delta \%)$

$\begin{array}{llllll}0.2365^{* * *} & 0.2366^{* * *} & 0.2371^{* * *} & 0.2371^{* * *} & 0.2360^{* * *} & 0.2360^{* * *} \\ (0.0031) & (0.0031) & (0.0031) & (0.0031) & (0.0031) & (0.0079)\end{array}$

Second Home (lag, share of total) $\quad-0.0036^{\star *}$

$-0.0039^{* *}-0.0039^{*}$

$(0.0018)$

$(0.0018) \quad(0.0021)$

Short-term Buyers (lag, share of total)

$-0.0038^{* * *}$

$-0.0037^{* * *}-0.0037^{* * *}$

$(0.0007)$

$(0.0007) \quad(0.0011)$

Corporate Cash (lag, share of total)

$\begin{array}{lll}-0.0005 & -0.0002 & -0.0002 \\ (0.0003) & (0.0004) & (0.0005)\end{array}$

$\begin{array}{lll}(0.0003) & (0.0004) \quad(0.0005)\end{array}$

Out-of-state (lag, share of total)

$\begin{array}{lll}-0.0017^{* *} & -0.0019^{* * *} & -0.0019^{*} \\ (0.0007) & (0.0007) & (0.0011)\end{array}$

Constant

$\begin{array}{llllll}-0.2271^{* * *} & -0.2011^{* * *} & -0.2296^{* * *} & -0.2333^{* * *} & -0.1731^{* * *} & -0.1731^{*} \\ (0.0300) & (0.0310) & (0.0312) & (0.0302) & (0.0319) & (0.1050)\end{array}$

\begin{tabular}{lllllll}
\hline Quarter FE & Yes & Yes & Yes & Yes & Yes & Yes \\
Zip code FE & Yes & Yes & Yes & Yes & Yes & Yes \\
Observations & 315248 & 315945 & 317114 & 317114 & 314083 & 314083 \\
Number of Clusters & 11227 & 11227 & 11227 & 11227 & 11227 & 1382 \\
Adjusted R-squared & 0.1671 & 0.1672 & 0.1670 & 0.1670 & 0.1674 & 0.1674 \\
\hline
\end{tabular}

Sources: Zillow's ZTRAX data and authors' calculations.

Note: This table presents results from estimating regressions around the following main specification:

$\Delta \ln (\text { rent })_{i t}=\alpha_{0}+\alpha_{h} \Delta \ln (h r)_{i, t-h}+\beta_{1} * S H I_{i, t-h}+\beta_{2} * S T B_{i, t-h}+\beta_{3} * L L C_{i, t-h}+\beta_{4} *$ Out $_{i, t-h}+v_{i}+\xi_{t}+\gamma_{i, t}+\epsilon_{i t}$

where $\Delta \ln (\text { rent })_{\text {it }}$ is the quarterly log change in the rental index of each zip code. For each quarter $\mathrm{t}, \mathrm{SHI}_{\mathrm{I}, \mathrm{t}}$ denotes the zip code-level share of secondhome investors, $\mathrm{STB}_{\mathrm{I}, \mathrm{t}}$ denotes the zip code-level share of within-year resales (flippers), LLC $_{\mathrm{It}}$ is the share of transactions by institutional investors in cash within the zip code, and Out $\mathrm{I}_{\mathrm{It}}$ is the share of transactions by out-of-state buyers. Estimations concern 2010Q1-2018Q4 period, for which the rental index data are available. All regressors are lagged one quarter. All regressions control for zip code- and quarter-fixed effects. Standard errors are clustered at the zip code-level. ${ }^{* * *},{ }^{* *},{ }^{*}$ indicate statistical significance at the 1 percent, 5 percent, and 10 percent level, respectively. 


\begin{tabular}{|c|c|c|c|c|c|c|c|c|c|c|c|c|c|}
\hline \multirow[b]{3}{*}{ Zipcodes with share non-bank lending: } & \multirow[t]{2}{*}{ (1) } & \multirow[t]{2}{*}{ (2) } & \multirow[t]{2}{*}{ (3) } & \multirow[t]{2}{*}{ (4) } & \multirow[t]{2}{*}{ (5) } & \multirow[t]{2}{*}{ (6) } & \multirow{2}{*}{\multicolumn{2}{|c|}{$\begin{array}{cc}(7) & (8) \\
\text { House prices }(\Delta \%, \text { qoq })\end{array}$}} & \multirow[t]{2}{*}{ (9) } & \multirow[t]{2}{*}{ (10) } & \multirow[t]{2}{*}{ (11) } & \multirow[t]{2}{*}{ (12) } & \multirow[t]{2}{*}{ (13) } \\
\hline & & & & & & & & & & & & & \\
\hline & High & Low & High & Low & High & Low & High & Low & High & Low & High & Low & $\mathrm{High}$ \\
\hline House prices (lag, $\Delta \%$ ) & $\begin{array}{c}0.7364^{* * *} \\
(0.0031)\end{array}$ & $\begin{array}{c}0.5611^{* * *} \\
(0.0046)\end{array}$ & $\begin{array}{c}0.7426 * * * \\
(0.0032)\end{array}$ & $\begin{array}{c}0.5621^{* * *} \\
(0.0046)\end{array}$ & $\begin{array}{c}0.7437^{* * *} \\
(0.0031)\end{array}$ & $\begin{array}{c}0.5628^{* * *} \\
(0.0046)\end{array}$ & $\begin{array}{c}0.7430^{* * *} \\
(0.0031)\end{array}$ & $\begin{array}{c}0.5630^{* * *} \\
(0.0046)\end{array}$ & $\begin{array}{c}0.7358^{* * *} \\
(0.0032)\end{array}$ & $\begin{array}{c}0.5600^{* * *} \\
(0.0046)\end{array}$ & $\begin{array}{c}0.5748^{* * *} \\
(0.0035)\end{array}$ & $\begin{array}{c}0.4584^{* * *} \\
(0.0041)\end{array}$ & $\begin{array}{r}0.7358 \\
0.018\end{array}$ \\
\hline Second Home (lag, share of total) & $\begin{array}{c}0.0047^{* * *} \\
(0.0014)\end{array}$ & $\begin{array}{l}-0.0008 \\
(0.0009)\end{array}$ & & & & & & & $\begin{array}{c}0.0049 * * * \\
(0.0015)\end{array}$ & $\begin{array}{l}-0.0012 \\
(0.0009)\end{array}$ & $\begin{array}{c}0.0004 \\
(0.0016)\end{array}$ & $\begin{array}{l}-0.0011 \\
(0.0009)\end{array}$ & $\begin{array}{l}0.0049 \\
10.002\end{array}$ \\
\hline Crisis \# Second Home (lag) & $\begin{array}{c}-0.0568 * * * \\
(0.0035)\end{array}$ & $\begin{array}{c}-0.0133 * * * \\
(0.0020)\end{array}$ & & & & & & & $\begin{array}{c}-0.0515^{* * *} \\
(0.0035)\end{array}$ & $\begin{array}{c}-0.0113^{* * * *} \\
(0.0020)\end{array}$ & $\begin{array}{c}0.0126 * * * \\
(0.0036)\end{array}$ & $\begin{array}{c}-0.0038^{* *} \\
(0.0017)\end{array}$ & $\begin{array}{r}-0.0519 \\
(0.024\end{array}$ \\
\hline Short-term Buyers (lag, share of total) & & & $\begin{array}{c}0.0093^{* * *} \\
(0.0005)\end{array}$ & $\begin{array}{c}0.0023^{* * *} \\
(0.0006)\end{array}$ & & & & & $\begin{array}{c}0.0078^{* * *} \\
(0.0005)\end{array}$ & $\begin{array}{c}0.0022^{* * *} \\
(0.0007)\end{array}$ & $\begin{array}{c}0.0026 * * * \\
(0.0006)\end{array}$ & $\begin{array}{c}0.0001 \\
(0.0006)\end{array}$ & $\begin{array}{l}0.0078 \\
(0.003\end{array}$ \\
\hline Crisis \# Short-term Buyers (lag) & & & $\begin{array}{l}-0.0174 * * * \\
(0.0012)\end{array}$ & $\begin{array}{c}-0.0104^{* * *} \\
(0.0016)\end{array}$ & & & & & $\begin{array}{c}-0.0204^{* * *} \\
(0.0012)\end{array}$ & $\begin{array}{l}-0.0082^{* * *}- \\
(0.0017)\end{array}$ & $\begin{array}{c}-0.0072^{* * *} \\
(0.0019)\end{array}$ & $\begin{array}{l}-0.0018 \\
(0.0016)\end{array}$ & $\begin{array}{r}-0.0204 \\
(0.004\end{array}$ \\
\hline Corporate Cash (lag, share of total) & & & & & $\begin{array}{c}0.0031^{* * *} \\
(0.0003)\end{array}$ & $\begin{array}{l}-0.0004 \\
(0.0003)\end{array}$ & & & $\begin{array}{c}0.0019^{* * *} \\
(0.0003)\end{array}$ & $\begin{array}{c}-0.0009 * * \\
(0.0003)\end{array}$ & $\begin{array}{c}0.0012^{* * *} \\
(0.0003)\end{array}$ & $\begin{array}{l}-0.0005 \\
(0.0004)\end{array}$ & $\begin{array}{r}0.0019 \\
(0.000\end{array}$ \\
\hline Crisis \# Corporate Cash (lag) & & & & & $\begin{array}{l}0.0008^{*} \\
(0.0004)\end{array}$ & $\begin{array}{c}-0.0029 * * * \\
(0.0008)\end{array}$ & & & $\begin{array}{c}0.0037^{* * *} \\
(0.0004)\end{array}$ & $\begin{array}{l}-0.0005 \\
(0.0008)\end{array}$ & $\begin{array}{c}-0.0016^{* * *} \\
(0.0004)\end{array}$ & $\begin{array}{c}0.0002 \\
(0.0008)\end{array}$ & $\begin{array}{l}0.0037 \\
(0.001\end{array}$ \\
\hline Out-of-state (lag, share of total) & & & & & & & $\begin{array}{c}0.0019 * * * \\
(0.0006)\end{array}$ & $\begin{array}{l}-0.0000 \\
(0.0004)\end{array}$ & $\begin{array}{l}0.0010^{*} \\
(0.0006)\end{array}$ & $\begin{array}{l}-0.0006^{*} \\
(0.0004)\end{array}$ & $\begin{array}{l}0.0014^{* *} \\
(0.0006)\end{array}$ & $\begin{array}{c}0.0002 \\
(0.0004)\end{array}$ & $\begin{array}{r}0.001 \\
(0.002\end{array}$ \\
\hline Crisis \# Out-of-state (lag) & & & & & & & $\begin{array}{c}-0.0029 \\
(0.0019)\end{array}$ & $\begin{array}{c}-0.0051^{* * *} \\
(0.0007)\end{array}$ & $\begin{array}{c}0.0055^{* * *} \\
(0.0017)\end{array}$ & $\begin{array}{c}-0.0032^{* * *} \\
(0.0007)\end{array}$ & $\begin{array}{l}0.0035^{*} \\
(0.0019)\end{array}$ & $\begin{array}{l}-0.0001 \\
(0.0007)\end{array}$ & $\begin{array}{r}0.005 \\
(0.004\end{array}$ \\
\hline Constant & $\begin{array}{c}0.2546 * * * \\
(0.0229)\end{array}$ & $\begin{array}{c}0.6773^{* * *} \\
(0.0485)\end{array}$ & $\begin{array}{c}0.1662^{* * *} \\
(0.0236)\end{array}$ & $\begin{array}{c}0.6687^{* * *} \\
(0.0487)\end{array}$ & $\begin{array}{c}0.2086^{* * *} \\
(0.0233)\end{array}$ & $\begin{array}{c}0.6706^{* * *} \\
(0.0481)\end{array}$ & $\begin{array}{c}0.2340^{* * *} \\
(0.0234)\end{array}$ & $\begin{array}{c}0.6623^{* * *} \\
(0.0509)\end{array}$ & $\begin{array}{c}0.1503^{* * *} \\
(0.0241)\end{array}$ & $\begin{array}{c}0.6524^{* * *} \\
(0.0509)\end{array}$ & $\begin{array}{c}0.3173^{* * *} \\
(0.0268)\end{array}$ & $\begin{array}{c}1.1772^{* * *} \\
(0.2454)\end{array}$ & $\begin{array}{r}0.150 \\
(0.122\end{array}$ \\
\hline Quarter FE & Yes & Yes & Yes & Yes & Yes & Yes & Yes & Yes & Yes & Yes & Yes & Yes & Yes \\
\hline Zip code FE & Yes & Yes & Yes & Yes & Yes & Yes & Yes & Yes & Yes & Yes & Yes & Yes & Yes \\
\hline Year-State FE & No & No & No & No & No & No & No & No & No & No & Yes & Yes & No \\
\hline Observations & 244760 & 173774 & 241511 & 175353 & 244064 & 176014 & 244992 & 175466 & 238916 & 171117 & 238916 & 171117 & 23891 \\
\hline Number of Clusters & 3891 & 4373 & 3887 & 4377 & 3886 & 4376 & 3891 & 4388 & 3882 & 4349 & 3882 & 4349 & 38 \\
\hline Adjusted R-squared & 0.7896 & 0.5698 & 0.7894 & 0.5710 & 0.7889 & 0.5707 & 0.7889 & 0.5710 & 0.7914 & 0.5708 & 0.8180 & 0.6070 & 0.791 \\
\hline 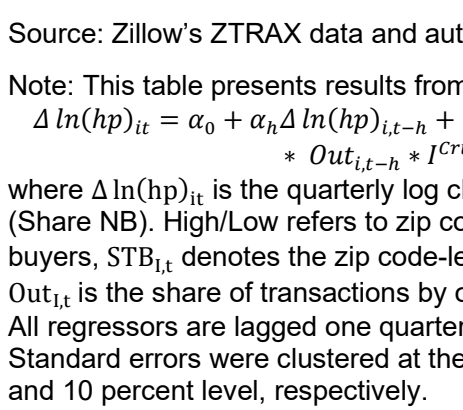 & $\begin{array}{l}\text { estimating re } \\
\beta_{1} * S H I_{i, t-h} \\
\text { is }+v_{i}+\xi_{t}+ \\
\text { lange in the r } \\
\text { des in top/bo } \\
\text { vel share of } \\
\text { ut-of-state bc } \\
\text { All regressic } \\
\text { zip code-lev }\end{array}$ & $\begin{array}{l}\text { tions. } \\
\text { regressions } \\
+\theta_{1} * S H I \\
+\gamma_{i, t}+\epsilon_{i t} \\
\text { median hou } \\
\text { ottom quarti } \\
\text { within-year } \\
\text { uyers. I }{ }^{\text {Crisi }} \\
\text { ions control } \\
\text { el in regres }\end{array}$ & $\begin{array}{l}\text { S around the } \\
I_{i, t-h} * I^{C r i s i} \text {. } \\
\text { use value c } \\
\text { tile of the cr } \\
r \text { resales (fli } \\
\text { is is an indi } \\
\text { for zip cod } \\
\text { ssions (1)-( }\end{array}$ & $\begin{array}{l}\text { ee following } \\
\text { sis }+\beta_{2} * S T \\
\text { of each zip } \\
\text { ross-time d } \\
\text { flippers), LL } \\
\text { licator varial } \\
\text { de-, quarte } \\
\text { (12) and st }\end{array}$ & $\begin{array}{l}\text { main spec } \\
T B_{i, t-h}+\theta_{2} \\
\text { o code. The } \\
\text { distribution. } \\
\mathrm{LC}_{\mathrm{I}, \mathrm{t}} \text { is the } \mathrm{s} \\
\text { able equal t } \\
\text { r- fixed effe } \\
\text { tate-level in }\end{array}$ & $\begin{array}{l}\text { cification: } \\
2 * S T B_{i, t-h} \\
\text { e zip code s } \\
\text {. For each } \\
\text { share of tra } \\
\text { to } 1 \text { during } \\
\text { fects, while } \\
\text { n (13)-(14). }\end{array}$ & $\begin{array}{l}{ }_{h}^{*} I^{\text {Crisis }}+ \\
\text { sample is } \mathrm{S} \\
\text { quarter } \mathrm{t}, \mathrm{S} \\
\text { ansactions } \\
\text { the GFC (2 } \\
\text { regression } \\
{ }^{* \star *},{ }^{* \star},{ }^{*} \text { in }\end{array}$ & $\begin{array}{l}-\beta_{3} * L L C_{i, t} \\
\text { split based } \\
\text { SHI } \\
\text { by corporat } \\
\text { (2007-09). } \\
\text { ns (11)-(12) } \\
\text { ndicate stati }\end{array}$ & $\begin{array}{l}t-h+\theta_{3} * \\
\text { on the ave } \\
\text { tes the zip } \\
\text { ate investor } \\
\text { Estimations } \\
\text { tinclude ac } \\
\text { tistical signi }\end{array}$ & $\begin{array}{l}L L C_{i, t-h} * I^{\complement} \\
\text { erage share } \\
\text { code-level } \\
\text { rs in cash w } \\
\text { is concern } \\
\text { additionally } \\
\text { nificance at }\end{array}$ & $\begin{array}{l}I^{\text {Crisis }}+\beta_{4} * \\
\text { e of shadov } \\
\text { within the zi } \\
\text { 1998Q1-20 } \\
\text { state-year } \\
t \text { the } 1 \text { perce }\end{array}$ & $\begin{array}{l}* \text { Out }_{i, t-h}+ \\
\text { w bank lenc } \\
\text { second-hom } \\
\text { zip code, an } \\
018 Q 4 \text { peric } \\
\text { fixed effect } \\
\text { cent, } 5 \text { perc }\end{array}$ & $\begin{array}{l}+\theta_{4} \\
\text { nding } \\
\text { me } \\
\text { ind } \\
\text { iod. } \\
\text { cts. } \\
\text { cent, }\end{array}$ \\
\hline
\end{tabular}




\begin{tabular}{|c|c|c|c|c|c|c|c|c|c|}
\hline & $(1)$ & $(2)$ & (3) & (4) & (5) & (6) & (7) & (8) & (9) \\
\hline & \multicolumn{9}{|c|}{ House prices $(\Delta \%, q \circ q)$} \\
\hline House prices (lag, $\Delta \%$ ) & $\begin{array}{c}0.7051^{* * *} \\
(0.0021)\end{array}$ & $\begin{array}{c}0.7035^{* * *} \\
(0.0020)\end{array}$ & $\begin{array}{c}0.6977^{* * *} \\
(0.0020)\end{array}$ & $\begin{array}{c}0.6966 * * * \\
(0.0020)\end{array}$ & $\begin{array}{c}0.7057^{* * *} \\
(0.0021)\end{array}$ & $\begin{array}{c}0.7059 * * * \\
(0.0021)\end{array}$ & $\begin{array}{c}0.7043 * * * \\
(0.0021)\end{array}$ & $\begin{array}{c}0.7043^{* * *} \\
(0.0102)\end{array}$ & $\begin{array}{c}0.7043^{* * *} \\
(0.0251)\end{array}$ \\
\hline Shadow banking (lag, share) & $\begin{array}{c}0.0003^{* * *} \\
(0.0001)\end{array}$ & $\begin{array}{c}0.0007^{* * *} \\
(0.0001)\end{array}$ & & & & & $\begin{array}{c}0.0007^{* * *} \\
(0.0001)\end{array}$ & $\begin{array}{c}0.0007^{* * *} \\
(0.0002)\end{array}$ & $\begin{array}{l}0.0007^{*} \\
(0.0004)\end{array}$ \\
\hline Crisis \# shadow banking (lag) & & $\begin{array}{c}-0.0032^{* * *} \\
(0.0002)\end{array}$ & & & & & $\begin{array}{c}-0.0033^{* * *} \\
(0.0002)\end{array}$ & $\begin{array}{c}-0.0033^{* * *} \\
(0.0005)\end{array}$ & $\begin{array}{c}-0.0033^{* * *} \\
(0.0011)\end{array}$ \\
\hline High LTV (lag, share of total) & & & $\begin{array}{c}0.0005^{* * *} \\
(0.0001)\end{array}$ & $\begin{array}{c}0.0001 \\
(0.0001)\end{array}$ & & & & & \\
\hline Crisis \# share high LTV (lag) & & & & $\begin{array}{c}0.0026^{* * *} \\
(0.0002)\end{array}$ & & & & & \\
\hline ARM (lag, share of total) & & & & & $\begin{array}{c}-0.0007^{* * *} \\
(0.0001)\end{array}$ & $\begin{array}{c}-0.0005^{* * *} \\
(0.0001)\end{array}$ & $\begin{array}{c}-0.0006 * * * \\
(0.0001)\end{array}$ & $\begin{array}{c}-0.0006^{* * *} \\
(0.0002)\end{array}$ & $\begin{array}{l}-0.0006 \\
(0.0003)\end{array}$ \\
\hline Crisis \# Share ARM (lag) & & & & & & $\begin{array}{c}-0.0012 * * * \\
(0.0002)\end{array}$ & $\begin{array}{c}-0.0015^{* * *} \\
(0.0002)\end{array}$ & $\begin{array}{c}-0.0015^{*} \\
(0.0007)\end{array}$ & $\begin{array}{l}-0.0015 \\
(0.0016)\end{array}$ \\
\hline Constant & $\begin{array}{c}0.4405^{* * *} \\
(0.0168)\end{array}$ & $\begin{array}{c}0.4159 * * * \\
(0.0169)\end{array}$ & $\begin{array}{c}0.4443^{* * *} \\
(0.0162)\end{array}$ & $\begin{array}{c}0.4632 * * * \\
(0.0163)\end{array}$ & $\begin{array}{c}0.4572 * * * \\
(0.0161)\end{array}$ & $\begin{array}{c}0.4574 * * * \\
(0.0161)\end{array}$ & $\begin{array}{c}0.4179 * * * \\
(0.0169)\end{array}$ & $\begin{array}{c}0.4179 * * * \\
(0.0804)\end{array}$ & $\begin{array}{c}0.4179 * * * \\
(0.1159)\end{array}$ \\
\hline Quarter FE & Yes & Yes & Yes & Yes & Yes & Yes & Yes & Yes & Yes \\
\hline Zip code FE & Yes & Yes & Yes & Yes & Yes & Yes & Yes & Yes & Yes \\
\hline Year-State FE & No & No & No & No & No & No & No & No & No \\
\hline Observations & 659337 & 659337 & 740124 & 740124 & 655372 & 655372 & 655372 & 655372 & 655372 \\
\hline Number of Clusters & 15826 & 15826 & 16307 & 16307 & 15789 & 15789 & 15789 & 1643 & 40 \\
\hline Adjusted R-squared & 0.7312 & 0.7314 & 0.7181 & 0.7183 & 0.7323 & 0.7323 & 0.7325 & 0.7325 & 0.7325 \\
\hline $\begin{array}{l}\text { Sources: Zillow's ZTRAX data } \\
\text { Note: This table presents rest } \\
\begin{array}{r}\Delta \ln (h p)_{i t}=\alpha_{0}+\alpha_{h} \Delta \ln (h p)_{i, t} \\
+\theta_{h}^{3} * A \\
\text { Where } \Delta \ln (\mathrm{hp})_{\text {it }} \text { is the quarte } \\
\text { zip code, NonBank } \\
\text { an indicator variable equal to } \\
\text { (10) includes state-year fixed } \\
\text { level in }(9)-(10) .{ }^{* *},{ }^{* *},{ }^{*} \text { deno }\end{array}\end{array}$ & $\begin{array}{l}+\beta_{1} * \text { NonB } \\
\Lambda_{i, t-h} * I^{\text {Crisis }} \\
\text { log change ir } \\
\text { of mortgage } \\
\text { during crisis y } \\
\text { fects as well. } \\
\text { statistical sig }\end{array}$ & 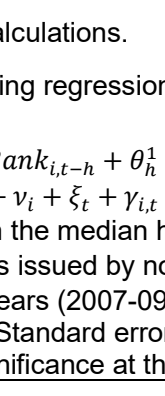 & $\begin{array}{l}\text { Is around the } \\
* \text { NonBank } k_{i, t} \\
+\epsilon_{i t} \\
\text { ouse value in } \\
\text { n-bank lende } \\
\text { ). Control vari } \\
\text { s are clustere } \\
\text { e } 1 \text { percent, } 5\end{array}$ & $\begin{array}{l}\text { following ma } \\
-h * I^{\text {Crisis }}+ \\
\text { each zip coc } \\
\text { rs, and } \mathrm{LTV}_{\mathrm{I}, \mathrm{t}} \\
\text { ables are lag } \\
\mathrm{d} \text { at the zip c } \\
\text { percent, anc }\end{array}$ & $\begin{array}{l}B_{2} * L T V_{i, t-h}+ \\
\text { le. ARM }{ }_{\mathrm{I}, \mathrm{t}} \text { den } \\
\text { is the share o } \\
\text { ged one quart } \\
\text { ode-level in r } \\
10 \text { percent le }\end{array}$ & $\begin{array}{l}\theta_{h}^{2} * L T V_{i, t-h} \\
\text { otes the share } \\
\mathrm{f} \text { mortgages } \mathrm{v} \\
\text { er. All regress } \\
\text { gressions (1) } \\
\text { vel, respectiv }\end{array}$ & $\begin{array}{l}* I^{\text {crisis }}+\beta_{3} \\
\text { of adjustable } \\
\text { ith LTV highe } \\
\text { ions control f } \\
\text {-(7), at the FIF } \\
\text { ely. }\end{array}$ & $\begin{array}{l}\text { * } A R M_{i, t-h} \\
\text { rate mortgag } \\
\text { r than } 90 \text { per } \\
\text { or zip code, q } \\
\text { PS-level in (8) }\end{array}$ & $\begin{array}{l}\text { es within the } \\
\text { lent. I }{ }^{\text {Crisis }} \text { is } \\
\text { arter, and } \\
\text { and state- }\end{array}$ \\
\hline
\end{tabular}




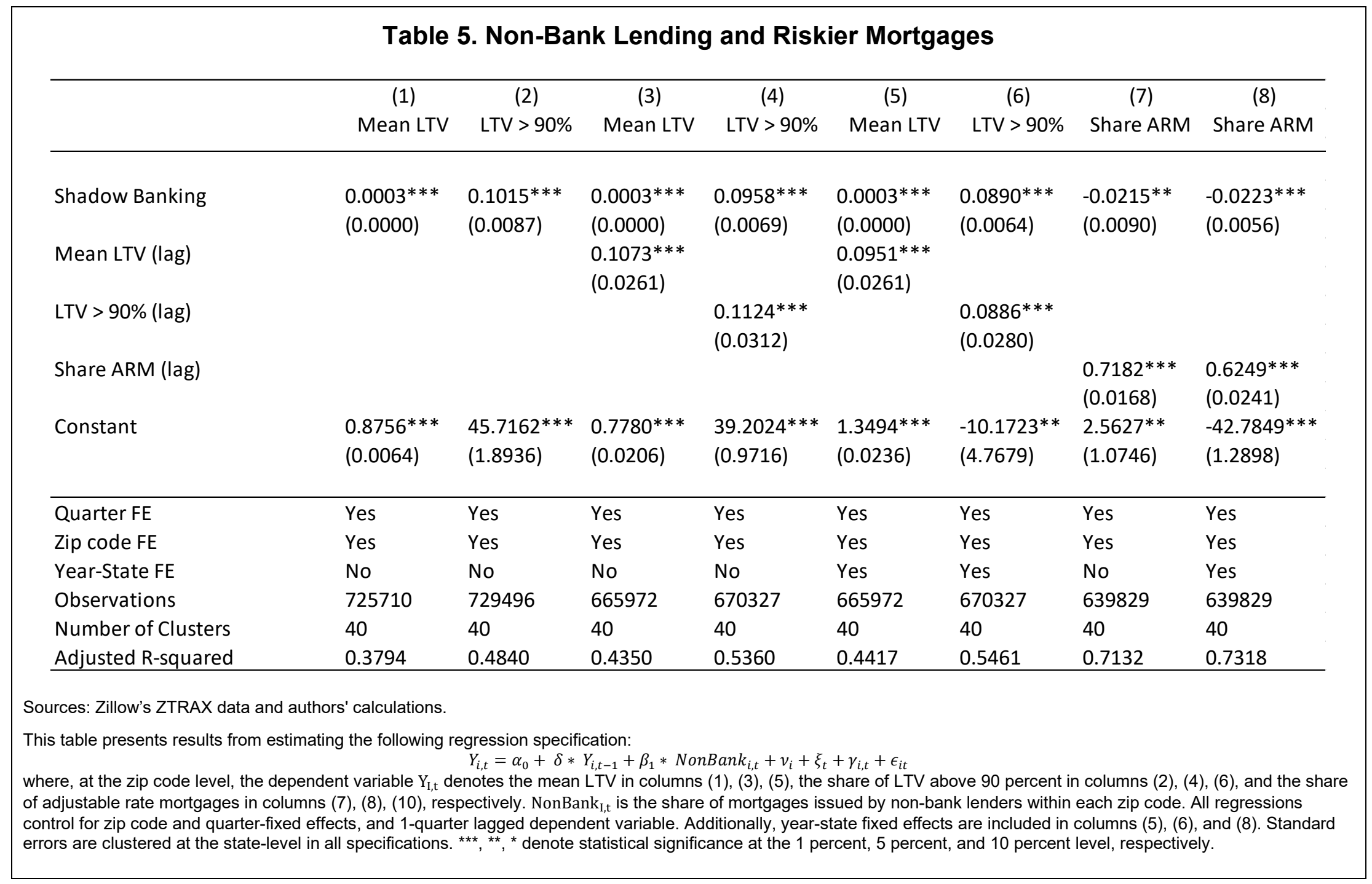


Table 6. First Look Program and Non-Primary Home Demand

\begin{tabular}{|c|c|c|c|c|}
\hline & (1) & $(2)$ & (3) & (4) \\
\hline & \multicolumn{2}{|c|}{ Second Home } & \multicolumn{2}{|c|}{ Corporate Cash } \\
\hline \multirow[t]{2}{*}{ Share First Look } & $0.0352 * * *$ & $0.0438 * * *$ & $0.7190 * * *$ & $0.3223 * * *$ \\
\hline & $(0.0060)$ & $(0.0059)$ & $(0.0642)$ & $(0.0282)$ \\
\hline \multirow[t]{2}{*}{ Post \# Share First Look } & $-0.0135 * *$ & $-0.0322 * * *$ & -0.0730 & $-0.1969 * * *$ \\
\hline & $(0.0058)$ & $(0.0057)$ & $(0.0613)$ & $(0.0275)$ \\
\hline \multirow[t]{2}{*}{ Second Home (lag) } & & $0.4909 * * *$ & & \\
\hline & & $(0.0073)$ & & \\
\hline \multirow[t]{2}{*}{ Corporate Cash (lag) } & & & & $0.6992 * * *$ \\
\hline & & & & $(0.0029)$ \\
\hline \multirow[t]{2}{*}{ Constant } & $3.4128 * * *$ & $1.6916 * * *$ & $12.5320 * * *$ & $3.5958 * * *$ \\
\hline & $(0.0449)$ & $(0.0417)$ & $(0.1006)$ & $(0.0664)$ \\
\hline Quarter FE & Yes & Yes & Yes & Yes \\
\hline Zip code FE & Yes & Yes & Yes & Yes \\
\hline Obs & 375514 & 375514 & 390981 & 390981 \\
\hline Number of Clusters & 14920 & 14920 & 15425 & 15425 \\
\hline Adjusted R-squared & 0.7515 & 0.8125 & 0.6782 & 0.8334 \\
\hline
\end{tabular}

Sources: Zillow's ZTRAX data and authors' calculations.

Note: This table presents results from estimating the following regression specification:

$$
Y_{i, t}=\alpha_{0}+\beta_{0} Y_{i, t-1}+\beta_{1} * F L_{i, t-1}+\beta_{2} * \text { Post }_{F L} * F L_{i, t-1}+v_{i}+\xi_{t}+\epsilon_{i t}
$$

where the dependent variable $Y_{\mathrm{II}}$ denotes the share of second-home buyers (columns 1-2) or the share of corporate cash buyers (columns 3-4). Post $\mathrm{FL}_{\mathrm{FL}}$ is a dummy variable denoting the period after the First Look program started, equal to 1 after $2009 \mathrm{Q} 3$ and 0 otherwise. The estimations use 1 -year moving average shares and the independent variables are lagged by one quarter. All regressions control for zip code and quarter-fixed effects. 
Table 7. House Prices and Non-Primary Home Demand - IV 2SLS Estimations

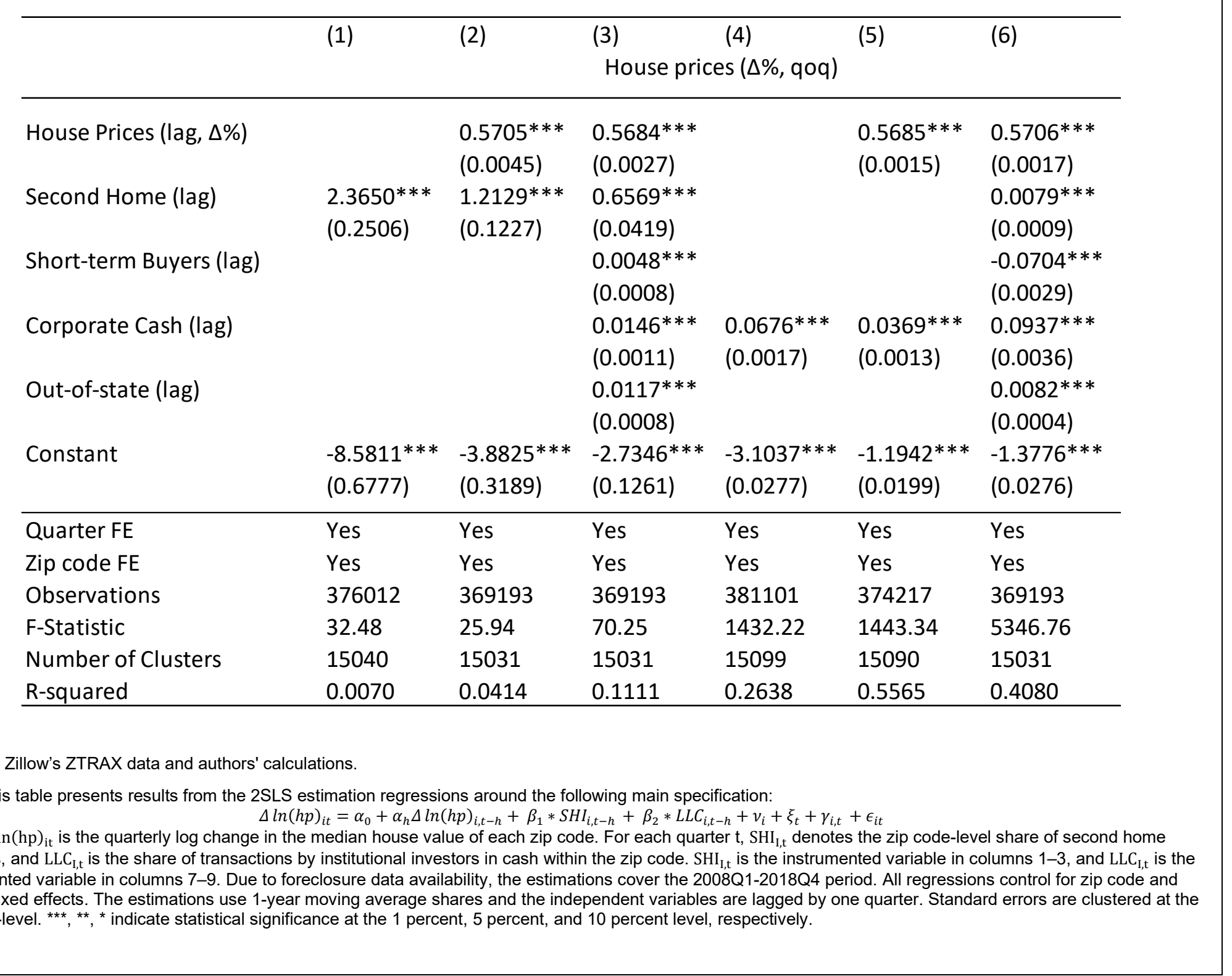


Table 8. Rental Index and Non-Primary Home Demand - IV 2SLS Estimations

\begin{tabular}{|c|c|c|c|c|c|c|}
\hline & (1) & (2) & (3) & (4) & (5) & (6) \\
\hline & \multicolumn{6}{|c|}{ Rents ( $\Delta \%$, qoq) } \\
\hline \multirow[t]{2}{*}{ Rents (lag, $\Delta \%$ ) } & & $0.2417 * * *$ & $0.2400 * * *$ & & $0.2396 * * *$ & $0.2385^{* * *}$ \\
\hline & & $(0.0040)$ & $(0.0028)$ & & $(0.0025)$ & $(0.0025)$ \\
\hline \multirow[t]{2}{*}{ Second Home (lag) } & $-1.5983 * * *$ & $-1.2786 * * *$ & $-0.5405^{* * *}$ & & & $-0.0076 * * *$ \\
\hline & $(0.1632)$ & $(0.1430)$ & $(0.0588)$ & & & $(0.0023)$ \\
\hline \multirow[t]{2}{*}{ Short-term Buyers (lag) } & & & $-0.0111 * * *$ & & & $0.0545^{* * *}$ \\
\hline & & & $(0.0014)$ & & & $(0.0063)$ \\
\hline \multirow[t]{2}{*}{ Corporate Cash (lag) } & & & $-0.0143 * * *$ & $-0.0495 * * *$ & $-0.0396 * * *$ & $-0.0844 * * *$ \\
\hline & & & $(0.0013)$ & $(0.0028)$ & $(0.0027)$ & $(0.0077)$ \\
\hline \multirow[t]{2}{*}{ Out-of-state (lag) } & & & $-0.0096 * * *$ & & & $-0.0084 * * *$ \\
\hline & & & $(0.0011)$ & & & $(0.0009)$ \\
\hline \multirow[t]{2}{*}{ Constant } & $2.6705^{* * *}$ & $2.4185 * * *$ & $1.3035 * * *$ & $0.3160 * * *$ & $0.4216 * * *$ & $0.6311 * * *$ \\
\hline & $(0.3271)$ & $(0.2932)$ & $(0.1441)$ & $(0.0547)$ & $(0.0487)$ & $(0.0672)$ \\
\hline Quarter FE & Yes & Yes & Yes & Yes & Yes & Yes \\
\hline Zipcode FE & Yes & Yes & Yes & Yes & Yes & Yes \\
\hline Observations & 252178 & 239517 & 239517 & 254396 & 241545 & 239517 \\
\hline F-Statistic & 17.22 & 17.14 & 48.10 & 1783.16 & 1639.90 & 4351.99 \\
\hline Number of Clusters & 11144 & 11098 & 11098 & 11153 & 11107 & 11098 \\
\hline R-squared & 0.0005 & 0.0028 & 0.0218 & 0.0861 & 0.1490 & 0.1040 \\
\hline
\end{tabular}

Sources: Zillow's ZTRAX data and authors' calculations.

Note: This table presents results from the 2SLS estimation regressions around the following main specification:

$\Delta \ln (\text { rent index })_{i t}=\alpha_{0}+\alpha_{h} \Delta \ln (\text { rent index })_{i, t-h}+\beta_{1} * S H I_{i, t-h}+\beta_{2} * L L C_{i, t-h}+v_{i}+\xi_{t}+\gamma_{i, t}+\epsilon_{i t}$

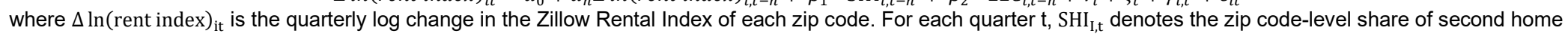
investors, and $\mathrm{LLC}_{\mathrm{I}, \mathrm{t}}$ is the share of transactions by institutional investors in cash within the zip code. $\mathrm{SHI}_{\mathrm{I}, \mathrm{t}}$ is the instrumented variable in columns $1-3$, and $\mathrm{LLC} \mathrm{I}_{\mathrm{I}, \mathrm{t}}$ is the instrumented variable in columns 7-9. Due to rental index data availability, the estimations cover the 2010Q3-2018Q4 period. The estimations use 1-year moving

average shares and the independent variables are lagged by one quarter. All regressions control for zip code and quarter-fixed effects. Standard errors are clustered at the zip code-level. ***, ${ }^{* *},{ }^{*}$ indicate statistical significance at the 1 percent, 5 percent, and 10 percent level, respectively. 


\section{REFERENCES}

Adelino, M., A. Schoar, and F. Severino, 2016. "Loan originations and defaults in the mortgage crisis: The role of the middle class," Review of Financial Studies, 29(7), 1635-70.

Adrian, T. and Ashcraft, A.B., 2012. "Shadow banking regulation," Annual Review of Financial Economics, 4(1), pp.99-140.

Albanesi, S., G. DeGiorgi, and J. Nosal, 2017. "Credit growth and the financial crisis: A new narrative," National Bureau of Economic Research Working Paper 23740.

Alter, A., and E. Mahoney, 2020. "Household debt and house prices-at-risk: A tale of two countries," IMF Working Paper 20/42.

Alter, A., J. Dokko, and M. Seneviratne, 2018. "House price synchronicity, banking integration, and global financial conditions,” IMF Working Paper 18/250.

Arellano, M., and S. Bond. 1991. "Some tests of specification for panel data: Monte Carlo evidence and an application to employment equations," Review of Economic Studies 58: 277-297.

Ari, A., D. Puy, and Y. Shi, 2020. "Are foreigners driving local house prices? Evidence from the U.S.," IMF Working Paper 20/43.

Armona, L., Fuster, A. and Zafar, B., 2019. "Home price expectations and behaviour: Evidence from a randomized information experiment," Review of Economic Studies, 86(4), pp.1371-1410.

Badarinza, C., and T. Ramadorai, 2018. "Home away from home? Foreign demand and London house prices," Journal of Financial Economics, 130(3), 532-55.

Bhutta, N., 2015. "The ins and outs of mortgage debt during the housing boom and bust," Journal of Monetary Economics, 76, 284-98.

Buchak, G., Matvos, G., Piskorski, T. and Seru, A., 2018. "Fintech, regulatory arbitrage, and the rise of shadow banks," Journal of Financial Economics, 130(3), pp.453-483.

Burnside, C., Eichenbaum, M. and Rebelo, S., 2016. "Understanding booms and busts in housing markets," Journal of Political Economy, 124(4), pp.1088-1147.

Chinco, A., and C. Mayer, 2016. "Misinformed speculators and mispricing in the housing market," Review of Financial Studies, 29(2), 486-522.

Claessens, S., 2015. “An overview of macroprudential policy tools," Annual Review of Financial Economics, 7, pp.397-422.

DeFusco, A.A., C.G. Nathanson, and E. Zwick, 2017. "Speculative dynamics of prices and volume," National Bureau of Economic Research, No. w23449.

Demyanyk, Y., and O. Van Hemert, 2011. "Understanding the subprime mortgage crisis," Review of Financial Studies, 24(6), 1848-80. 
Favilukis, J.Y., S.C. Ludvigson, and S. Van Nieuwerburgh, 2017. "The macroeconomic effects of housing wealth, housing finance, and limited risk sharing in general equilibrium," Journal of Political Economy, 125 (1), 140-223.

Favilukis, J.Y., and S. Van Nieuwerburgh, 2017. “Out-of-town home buyers and city welfare,” CEPR Discussion Paper No. DP12283.

Foucault, T., Sraer, D. and Thesmar, D.J., 2011. "Individual investors and volatility" Journal of Finance, 66(4), pp.1369-1406.

Fuster, A., and others, 2019. "The role of technology in mortgage lending," Review of Financial Studies, 32(5), 1854-99.

Gao, Z., M. Sockin, and W. Xiong, 2020. "Economic consequences of housing speculation,” Review of Financial Studies, 1-40.

Greenwald, D., and A. Guren, 2019. “Do credit conditions move house prices?” Unpublished manuscript, MIT.

Hundtofte, S., and V. Rantala, 2018. “Anonymous capital flows and U.S. housing markets," University of Miami Business School Research Paper, (18-3).

Justiniano, A., G.E. Primiceri, and A. Tambalotti, 2019. “Credit supply and the housing boom,” Journal of Political Economy, 127(3), 1317-50.

Keys, B.J., and others, 2010. "Did securitization lead to lax screening? Evidence from subprime loans," Quarterly Journal of Economics, 125(1), 307-62.

Lambie-Hanson, L., W. Li, and M. Slonkosky, 2019. "Leaving households behind: Institutional investors and the US housing recovery," Federal Reserve Bank of Philadelphia Working Paper No. 19-01.

Mian, A., and A. Sufi, 2009. "The consequences of mortgage credit expansion: Evidence from the US mortgage default crisis," Quarterly Journal of Economics, 124(4), 1449-96.

_ 2018a. "Credit supply and housing speculation," National Bureau of Economic Research Working Paper No. w24823.

_ 2018b. "Finance and business cycles: the credit-driven household demand channel," Journal of Economic Perspectives, 32(3), 31-58.

Mills, J., R. Molloy, and R. Zarutskie, 2019. "Large-scale buy-to-rent investors in the single-family housing market: The emergence of a new asset class," Real Estate Economics, 47(2), 399-430.

Nathanson, C.G., and E. Zwick, 2018. “Arrested development: Theory and evidence of supply-side speculation in the housing market," Journal of Finance, 73(6), 2587-2633. 
AnNeX

\begin{tabular}{|c|c|c|c|c|c|c|c|c|c|c|c|c|}
\hline \multicolumn{13}{|c|}{$\begin{array}{c}\text { Annex Table 1. Summary Statistics } \\
\text { (Transaction level) }\end{array}$} \\
\hline & \multicolumn{6}{|c|}{ All Transactions } & \multicolumn{6}{|c|}{ Loans Only } \\
\hline & $\mathrm{N}$ & mean & $\mathrm{sd}$ & $\min$ & p50 & $\max$ & $\mathrm{N}$ & mean & sd & $\min$ & $\mathrm{p} 50$ & $\max$ \\
\hline Sales Price Amount & $88,063,434$ & 234217 & 295962 & 2600 & 165000 & 10000000 & $49,763,801$ & 264128 & 272411 & 2600 & 195000 & 10000000 \\
\hline Loan Amount & $86,589,692$ & 123324 & 193600 & 0 & 78462 & 10000000 & $49,763,801$ & 214585 & 213621 & 1 & 166900 & 10000000 \\
\hline Bank Lender & $88,063,434$ & 0.1928 & 0.3945 & 0 & 0 & 1 & $49,763,801$ & 0.3375 & 0.4729 & 0 & 0 & 1 \\
\hline NonBank Lender & $88,063,434$ & 0.2354 & 0.4243 & 0 & 0 & 1 & $49,763,801$ & 0.4144 & 0.4926 & 0 & 0 & 1 \\
\hline Cash Transactions & $88,063,434$ & 0.4125 & 0.4923 & 0 & 0 & 1 & $49,763,801$ & 0 & 0 & 0 & 0 & 0 \\
\hline Corporate (cash) & $88,063,434$ & 0.1113 & 0.3145 & 0 & 0 & 1 & $49,763,801$ & 0 & 0 & 0 & 0 & 0 \\
\hline Corporate & $88,063,434$ & 0.1319 & 0.3383 & 0 & 0 & 1 & $49,763,801$ & 0.0322 & 0.1766 & 0 & 0 & 1 \\
\hline Out-of-State Buyers & $88,063,434$ & 0.0568 & 0.2314 & 0 & 0 & 1 & $49,763,801$ & 0.0479 & 0.2135 & 0 & 0 & 1 \\
\hline Bank Float Rate & $88,063,434$ & 0.0522 & 0.2224 & 0 & 0 & 1 & $49,763,801$ & 0.0922 & 0.2893 & 0 & 0 & 1 \\
\hline Bank Fixed Rate & $88,063,434$ & 0.1385 & 0.3455 & 0 & 0 & 1 & $49,763,801$ & 0.2415 & 0.4280 & 0 & 0 & 1 \\
\hline Bank Interest Mortgage & $88,063,434$ & 0.1897 & 0.3921 & 0 & 0 & 1 & $49,763,801$ & 0.3320 & 0.4709 & 0 & 0 & 1 \\
\hline NonBank Float Rate & $88,063,434$ & 0.0570 & 0.2319 & 0 & 0 & 1 & $49,763,801$ & 0.1008 & 0.3011 & 0 & 0 & 1 \\
\hline NonBank Fixed Rate & $88,063,434$ & 0.1784 & 0.3828 & 0 & 0 & 1 & $49,763,801$ & 0.3135 & 0.4639 & 0 & 0 & 1 \\
\hline NonBank Interest Mortgage & $88,063,434$ & 0.2354 & 0.4243 & 0 & 0 & 1 & $49,763,801$ & 0.4144 & 0.4926 & 0 & 0 & 1 \\
\hline Float Rate & $88,063,434$ & 0.1082 & 0.3107 & 0 & 0 & 1 & $49,763,801$ & 0.1913 & 0.3934 & 0 & 0 & 1 \\
\hline Fixed Rate & $88,063,434$ & 0.3169 & 0.4653 & 0 & 0 & 1 & $49,763,801$ & 0.5550 & 0.4970 & 0 & 1 & 1 \\
\hline LTV & $48,470,597$ & 0.8389 & 0.1708 & 0 & 0.82 & 1.5 & $48,470,597$ & 0.8389 & 0.1708 & 0 & 0.82 & 2 \\
\hline Bank LTV & $16,170,040$ & 0.8203 & 0.1726 & 0 & 0.80 & 1.5 & $16,170,040$ & 0.8203 & 0.1726 & 0 & 0.80 & 2 \\
\hline NonBank LTV & $20,309,603$ & 0.8558 & 0.1563 & 0 & 0.90 & 1.5 & $20,309,603$ & 0.8558 & 0.1563 & 0 & 0.90 & 2 \\
\hline Within-year Resale & $88,063,434$ & 0.0957 & 0.2942 & 0 & 0 & 1 & $49,763,801$ & 0.0388 & 0.1931 & 0 & 0.00 & 1 \\
\hline Conventional Loans & $49,769,959$ & 0.3056 & 0.4607 & 0 & 0 & 1 & $49,763,801$ & 0.3056 & 0.4606 & 0 & 0.00 & 1 \\
\hline Conforming Loans & $49,763,801$ & 0.2861 & 0.4519 & 0 & 0 & 1 & $49,763,801$ & 0.2861 & 0.4519 & 0 & 0.00 & 1 \\
\hline
\end{tabular}




\section{Annex Figure 1. Various Types of Non-Primary Home Buyers}

1. Non-primary home buyers (percent of total; total volume)

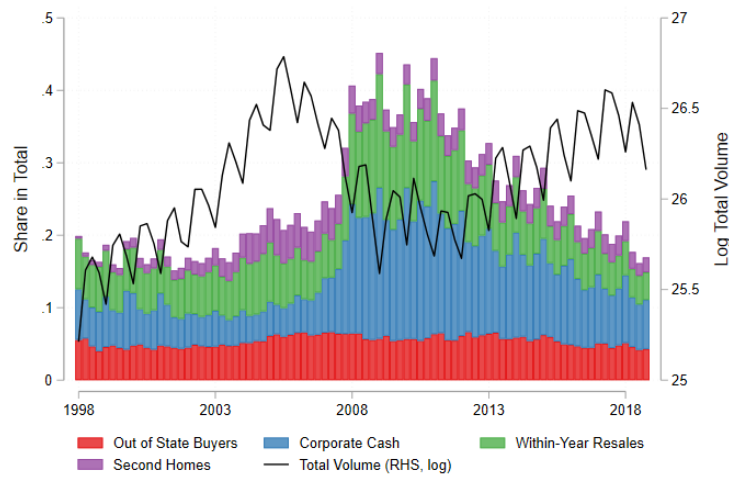

3. Share of cash transactions

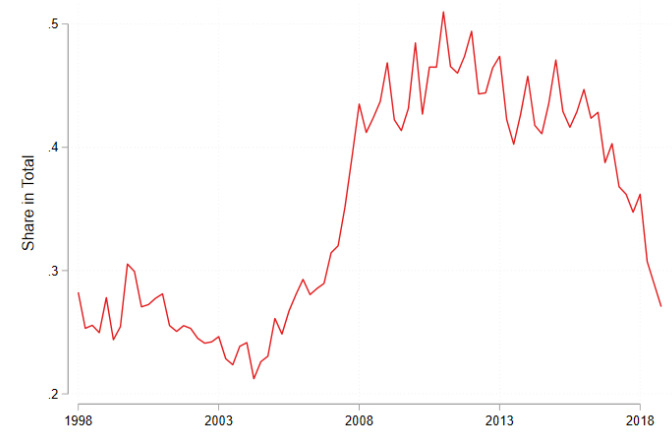

5. Cross-state distribution of out-of-state buyers

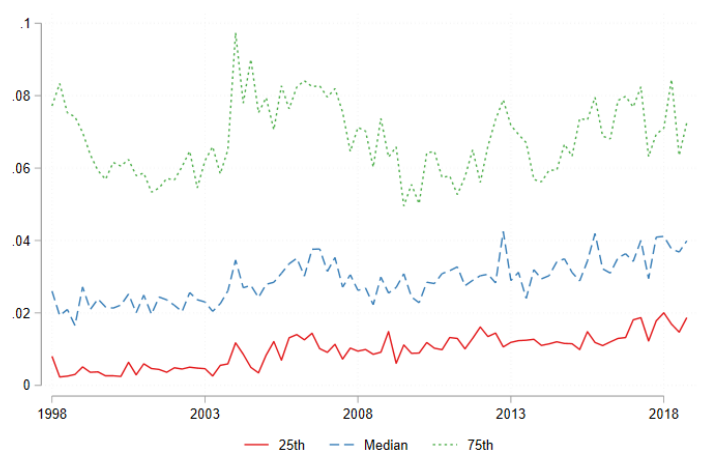

2. Share of short-term investors (within-year resales)

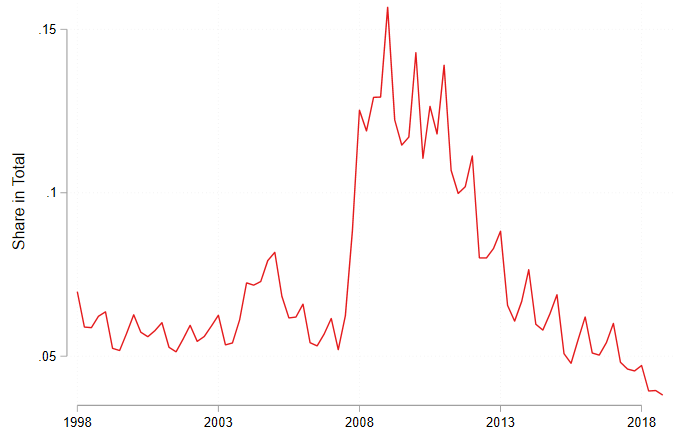

4. Cross-state distribution of corporate cash

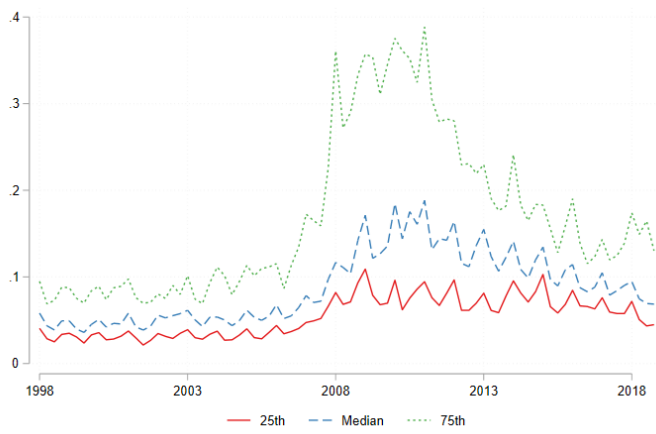

6. Cross-state distribution of second-home buyers

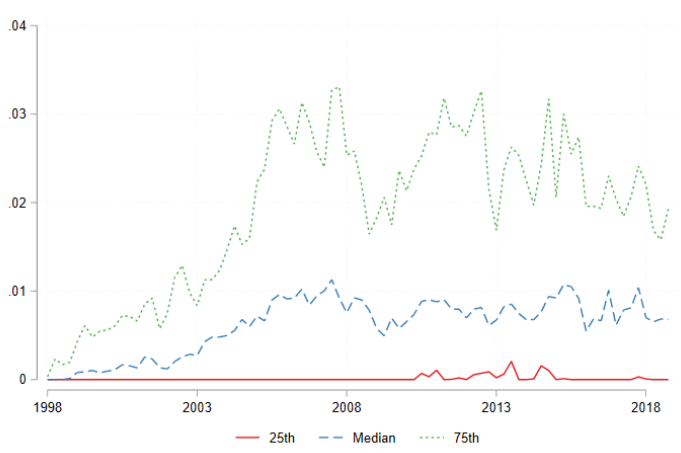

Sources: Zillow's ZTRAX data and authors' calculations.

Note: Panel 1 depicts each type of non-traditional investments as a share of total transactions, weighted by the sales price. Corporate cash transactions are a subset of all cash transactions. In panels $4-6,25$ th and 75 th represent the $25^{\text {th }}$ percentile and $75^{\text {th }}$ percentile of the cross-state distribution. 


\section{Annex Figure 2. Residential Mortgage Lending}

1. All mortgage originations: shares by lender type

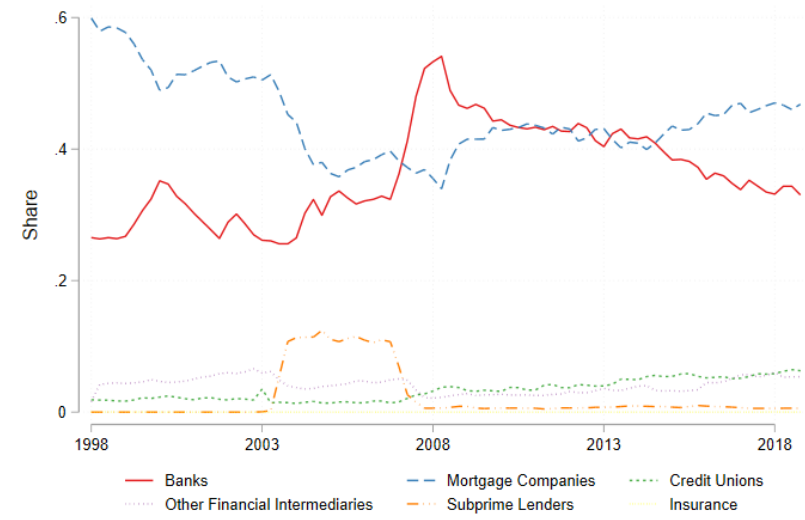

3. All mortgage originations: loan-to-value (LTV)

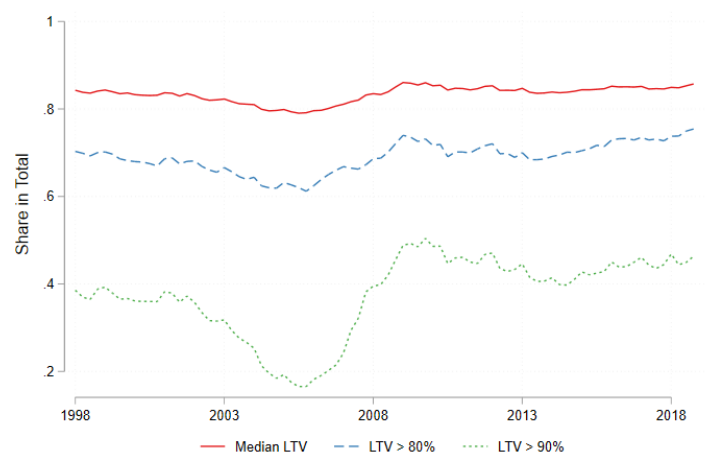

5. Cross-state distribution of adjustable rate mortgages (ARMs)

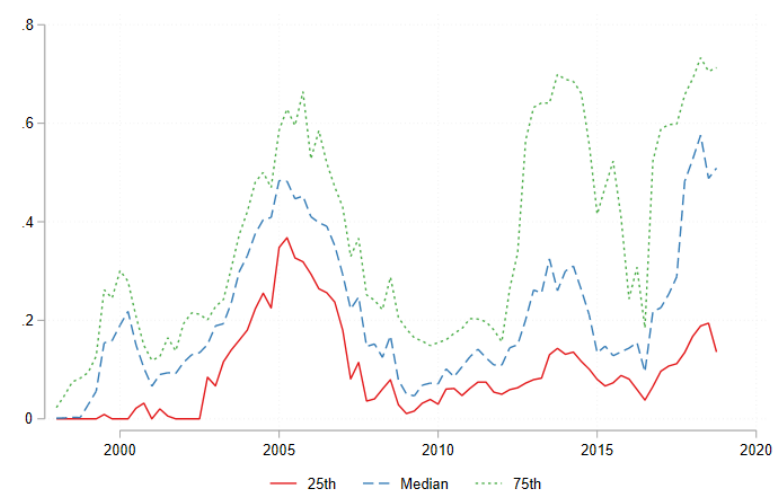

2. All mortgage originations: banks vs. non-banks

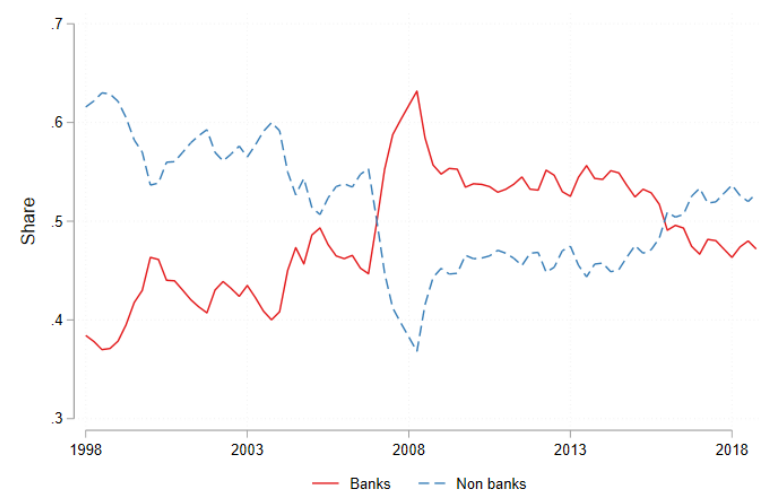

4. Originations of risky mortgages by lender type

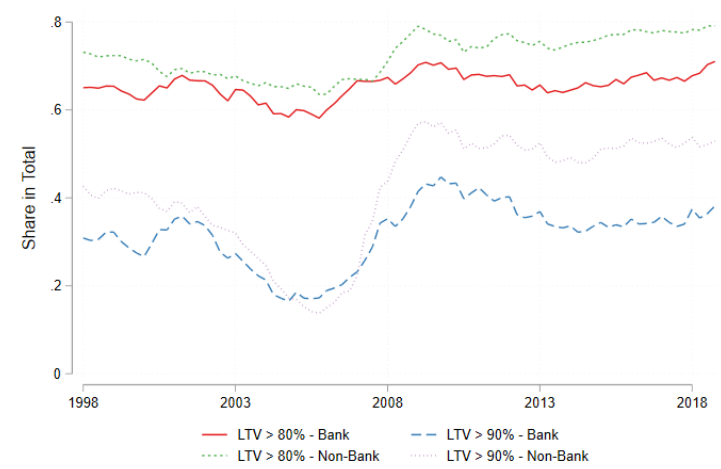

6. Adjustable rate mortgages (ARMs): banks vs. non-banks

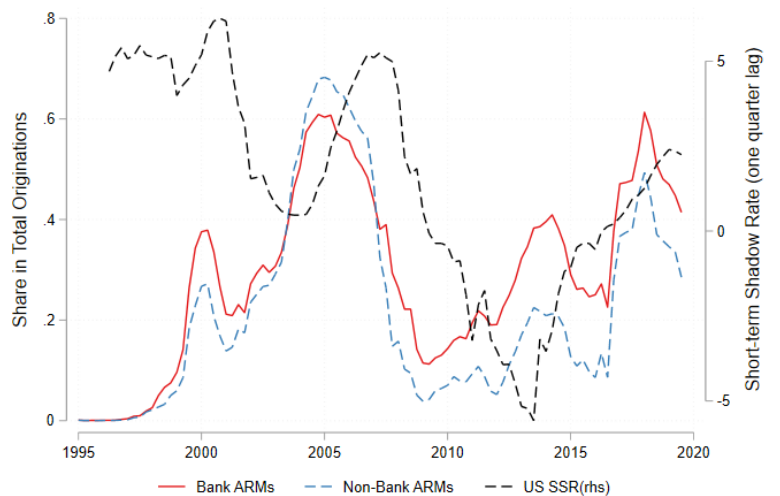

Sources: Zillow's ZTRAX data and authors' calculations.

Note: Non-banks include insurance, other financial intermediaries, subprime lenders, mortgage and finance companies. In panel 5 , 25th and 75 th represent the $25^{\text {th }}$ percentile and $75^{\text {th }}$ percentile of the cross-state distribution. 


\section{Annex Figure 3. Shadow Banking Activity across US Counties}

1. Share of shadow banking activity: 2008

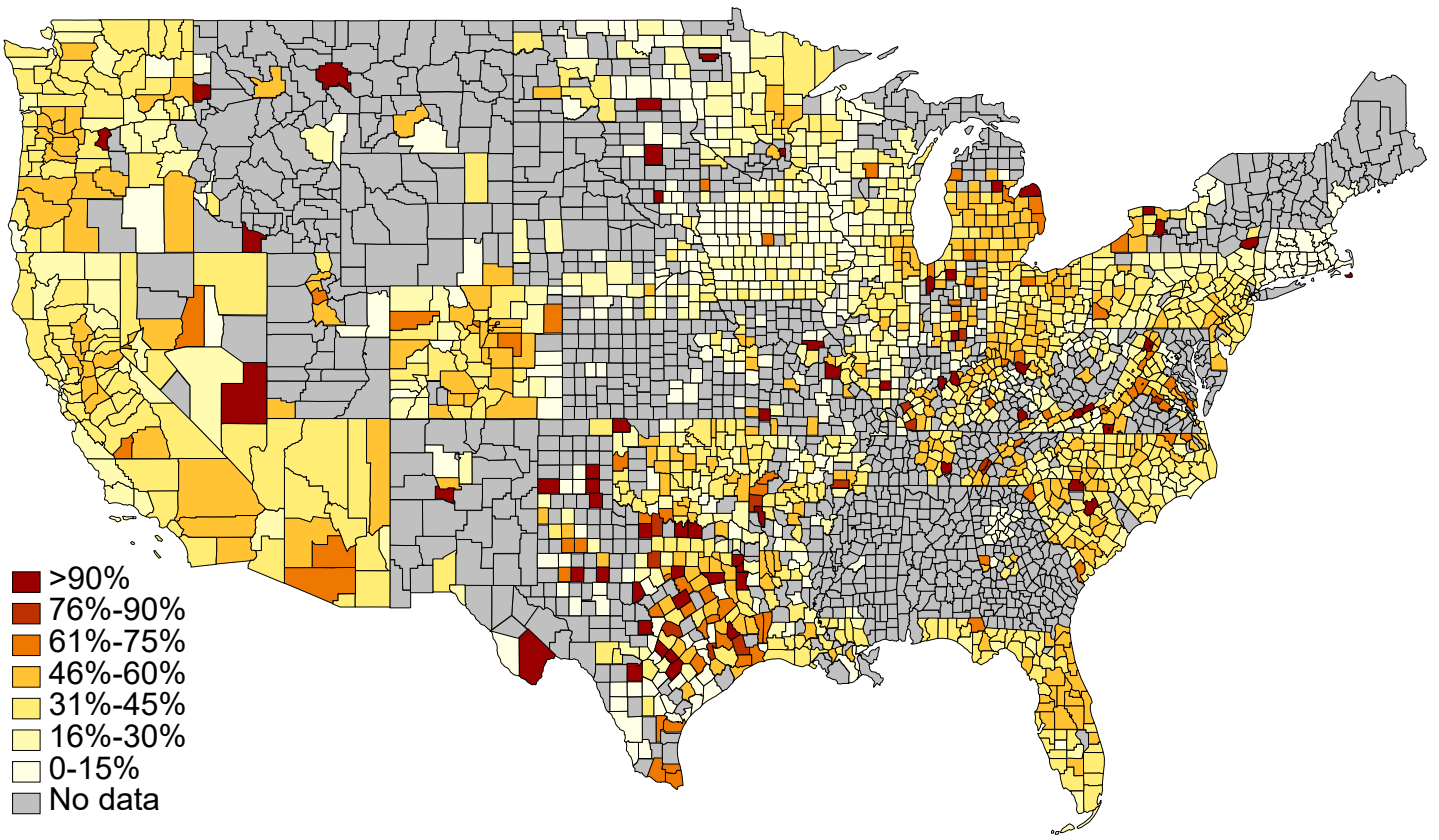

2. Share of shadow banking activity: 2018

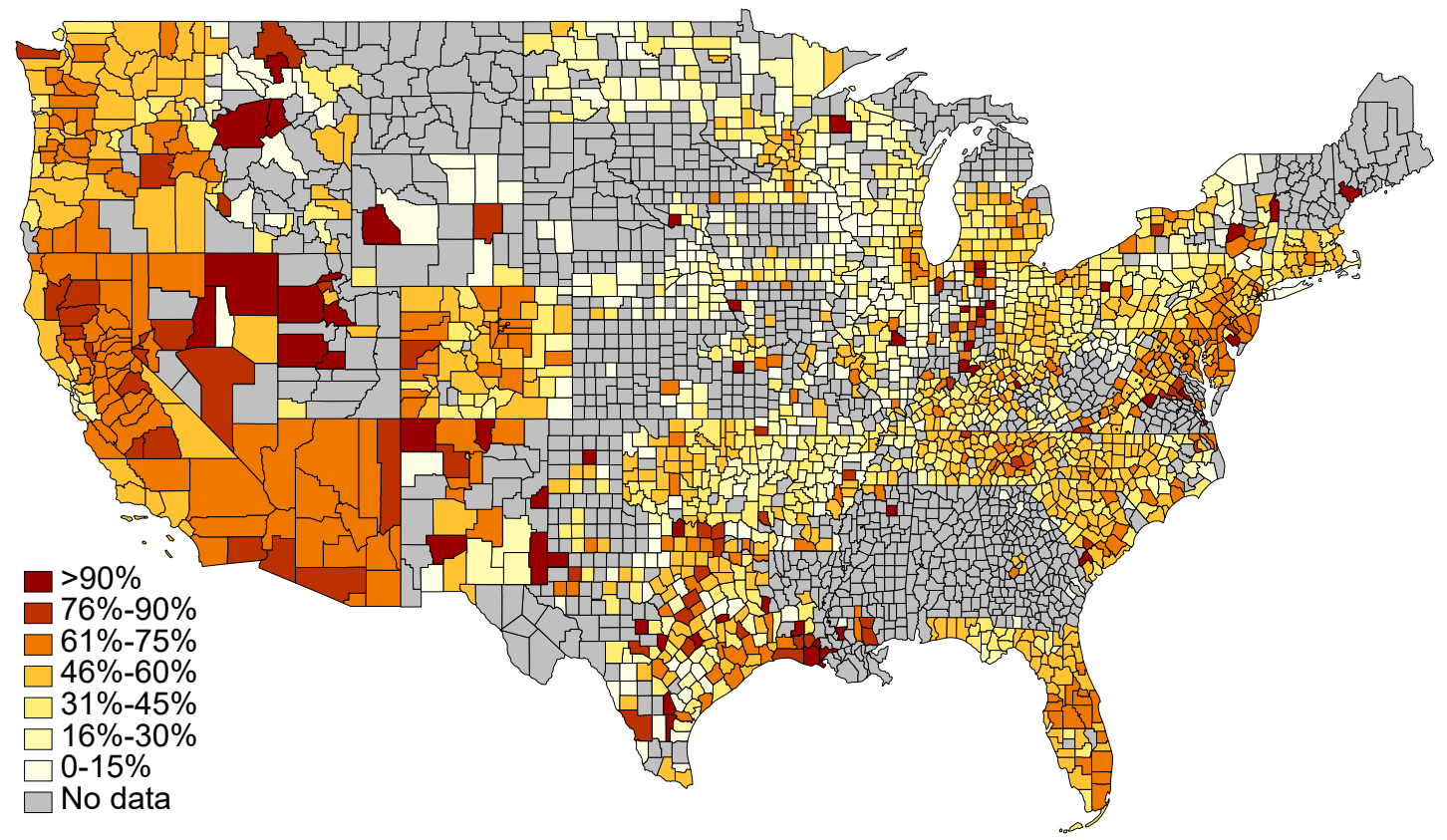

Sources: Zillow's ZTRAX data and authors' calculations.

Note: "Shadow banking" refers to non-deposit taking financial intermediaries such as mortgage and finance companies. 